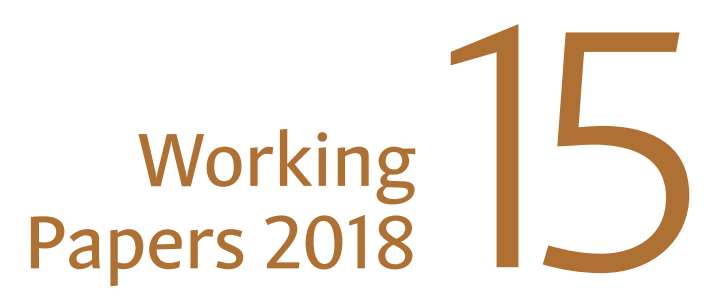

Cross-border spillovers of monetary policy: what changes during a financial crisis?

Luciana Barbosa | Diana Bonfim Sónia Costa | Mary Everett

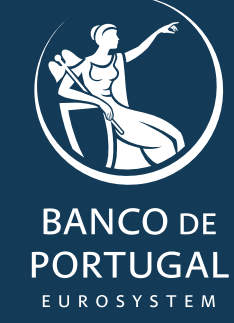





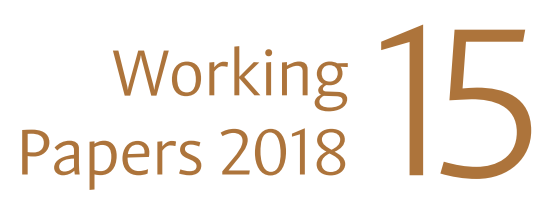

\title{
Cross-border spillovers of monetary policy: what changes during a financial crisis?
}

\author{
Luciana Barbosa | Diana Bonfim
} Sónia Costa | Mary Everett Banco de Portugal or the Eurosystem

Please address correspondence to Banco de Portugal, Economics and Research Department Av. Almirante Reis, 71, 1150-012 Lisboa, Portugal Tel.: +351 213130 000, email: estudos@bportugal.pt

BANCO DE PORTUGAL EUROSYSTEM

Lisbon, 2018 • www.bportugal.pt 
Working Papers | Lisbon 2018 • Banco de Portugal Av. Almirante Reis, 71 | 1150-012 Lisboa • www.bportugal.pt • Edition Economics and Research Department • ISBN (online) 978-989-678-592-5 • ISSN (online) 2182-0422 


\title{
Cross-border spillovers of monetary policy: what changes during a financial crisis?
}

\author{
Luciana Barbosa \\ Banco de Portugal \\ Sónia Costa \\ Banco de Portugal
}

\author{
Diana Bonfim \\ Banco de Portugal and Católica \\ Lisbon SBE \\ Mary Everett \\ Central Bank of Ireland
}

July 2018

\begin{abstract}
This paper analyses cross-border spillovers of monetary policy by examining two countries that were in the eye of the storm during the euro area sovereign debt crisis, namely Ireland and Portugal. The research provides insight as to how banking and sovereign stress affect the inward transmission of foreign monetary policy to two economies that share many characteristics, but that also have many distinct features. In particular, our research addresses the question of whether a banking system in distress reacts more or less to monetary policy changes in other major economies. The empirical analysis indicates that international spillovers are present for US and UK monetary policy for both Ireland and Portugal, but there is heterogeneity in the transmission mechanisms by which they affect credit growth in the two economies.
\end{abstract}

JEL: F60, G15, G21

Keywords: cross-border banking, euro area sovereign crisis, unconventional monetary policy spillovers, credit supply.

Acknowledgements: We would like to thank Jean-Stéphane Mésonnier, colleagues from the International Banking Research Network, and participants in seminars at Trinity College, Central Bank of Ireland, Banco de Portugal, and in the Global Financial Linkages and Monetary Policy Transmission conference for insightful comments and suggestions. Disclaimer: The views expressed in this paper are those of the authors and do not necessarily reflect those of the Central Bank of Ireland, Banco de Portugal, or the European System of Central Banks.

E-mail: llucianabarbosa@gmail.com; dbonfim@bportugal.pt; smcosta@bportugal.pt; mary.everett@centralbank.ie 


\section{Introduction}

Global factors, including the monetary policy stance of major economies, have been important determinants of financial conditions in advanced economies over the past 15 years. The period preceding the global financial crisis witnessed a surge in the international activities of global banks, reflected in an expansion of their balance sheets funded by the international wholesale markets, and manifested in the significant growth of cross-border banking flows during the mid-2000s (BIS 2011). Consequently, cross-border banking flows were the key channel through which permissive financing conditions in global financial markets were disseminated internationally (Bruno and Shin 2015).

Financial liberalisation, free movement of capital in the European Union, and the advent of the euro were also contributory factors determining the increases in cross-border banking inflows to Europe (Hale and Obstfeld 2014). Indeed, increasing financial globalisation has also motivated the focus of a number of studies on the international aspect of monetary policy transmission to domestic and cross-border credit supply (such as Ceterolli and Goldberg 2012, Correa et al. 2015, Bruno and Shin 2015).

This paper compares and contrasts the international spillovers of monetary policy from the US and UK to Ireland and Portugal. ${ }^{1}$ Ireland and Portugal warrant joint scrutiny for the study of international spillovers of monetary policy for a number of reasons. From a complementary perspective both countries (i) are small open economies, (ii) have a common currency, the euro, (iii) experienced considerable international leverage during the pre-crisis period, (iv) were at the crux of the euro area sovereign debt crisis, (v) relied heavily on Eurosystem official liquidity during the sovereign debt crisis, and (vi) needed to draw on international financial assistance from the IMF and European authorities.

However, despite these commonalities, the building blocks of the crises are quite different. In Ireland the crisis had its roots in a real estate bubble and in imbalances in the financial system (Honohan 2009). In contrast, for Portugal the crisis was more associated with structural weaknesses in the economy, which became unsustainable when access to international debt markets disappeared (Alves et al. 2016). These differences make this joint study even more valuable, as we can explore how different paths leading up to a crisis, in which the two economies were in the eye of the storm, can influence the international transmission of monetary policy. There are also important differences in the way the two countries have been recovering from the crisis, as well as on structural

1. The paper is part of a collective research project under the aegis of the International Banking Research Network (IBRN). As described in Buch et al. (2018), in this project researchers from 17 central banks use confidential bank-level data to explore the international transmission of monetary policy using a common methodological framework. For further details on the IBRN, visit https://www.newyorkfed.org/ibrn. 
characteristics of the economies, most notably in terms of competitiveness and degree of openness to trade (with potentially important impacts on the crossborder spillovers of monetary policy).

To study the transmission of monetary policy, it is crucial to consider the heterogeneity within the banking system (Kashyap and Stein 2000, Gambacorta and Marques-Ibanez 2011). This is even more important when covering a period of financial instability (Ciccarelli et al. 2013). We explore several bank-level characteristics related to funding and portfolio frictions that may influence the cross-border transmission of monetary policy. ${ }^{2}$

Funding frictions relate to the traditional literature on the bank lending channel, in which tightening a monetary policy decreases the supply of credit (Bernanke and Blinder 1988, Bernanke and Gertler 1995, Kashyap and Stein 1995). This channel might work across borders. Following a monetary policy tightening abroad, the value of banks' foreign currency liabilities increases and may be associated with a tightening of domestic financial conditions (Kearns and Patel 2016). To capture this, we consider the extent to which banks are exposed through cross-border liabilities to the countries where monetary policy is changing. We also examine the role that banks' liquidity might have in lessening the international pass-through of monetary policy.

Portfolio frictions relate to the fact that banks' choices in terms of asset composition and capital structure may also play an important role in shaping the transmission of monetary policy. On the one hand, banks with more assets whose value changes after a monetary policy decision abroad might be more likely to transmit the shock to credit granted at home, since they suffer a larger shock. On the other hand, banks with larger foreign exposures might be more prone to rebalance their portfolio between domestic and foreign assets when monetary policy changes abroad. For instance, a tightening of UK monetary policy reduces the creditworthiness of UK borrowers and their collateral values. Due to this increase in the perceived riskiness of foreign assets, banks might move away from foreign assets to domestic (perceived safer) assets. Both mechanisms are akin to the balance sheet channel of monetary policy, in which a tightening of monetary policy is associated with a deterioration in the net worth of borrowers and their collateral values (Bernanke and Gertler 1995).

We employ bank-level data from Ireland and Portugal to explore whether there are international spillovers of monetary policy to two small open economies that share a common currency. In addition, we analyse the key commonalities and differences of transmission before and during the euro area sovereign debt crisis. The empirical analysis shows that international spillovers are present for US and UK monetary policy, but the mechanisms through which they affect credit in Ireland and Portugal depend on the time period analysed.

2. The mechanisms of transmission used in this internationally coordinated research project are described in greater detail in Buch et al. (2018). 
Overall, the results indicate that international funding frictions are present for both economies prior to the euro area sovereign debt crisis. Furthermore, liquid assets play a mitigating role in offsetting a funding shock driven by changes in foreign monetary policy. During the sovereign debt crisis period, international funding frictions lose all relevance. These findings are in line with expectations given the international leverage of both banking systems during this period. ${ }^{3}$ After the crisis started banks in both countries became heavily dependent on domestic central bank official liquidity due predominantly to the retrenchment of international funding, thereby explaining the lack of evidence on cross-border transmission of monetary policy. ${ }^{4}$

The empirical analysis also shows that some portfolio decisions of banks work as frictions for the cross-border transmission of monetary policy, working as either amplification or mitigation mechanisms. The results are diametrically different for the two countries depending on the monetary policy measure used and the period under review. The empirical analysis indicates that prior to the crisis, the asset structure of Irish banks is irrelevant for the cross-border transmission of monetary policy. This possibly reflects the motivation of Irish banks to expand lending abroad in the pre-crisis period, which was driven by the desire to diversify their portfolios. ${ }^{5}$ After the crisis started these crossborder portfolio channels become operational for Ireland but lose relevance for Portugal. This possibly reflects the longer and deeper crisis experience in the Portuguese economy, as well as the prevalence of legacy assets in the banking system for a longer period (Blanchard and Portugal 2017).

The remainder of the paper is structured as follows. Section 2 presents the stylised facts on the evolution of imbalances and across the two economies since the start of the euro, and their subsequent unwinding during the euro area sovereign debt crisis. The data sources are described in Section 3. Section 4 provides the econometric specification and empirical approach. The empirical results are presented in Section 5. In Section 6 we discuss the most important results. Finally, Section 7 summarises and concludes the paper.

\section{Stylised facts and institutional background}

In this section we review the factors common to Ireland and Portugal that contributed to the build-up of macroeconomic imbalances in the context of euro area financial integration.

3. See Honohan (2009), Coates and Everett (2013), Everett (2015), Lane (2016) for details of the Irish banking system's international leverage. See Alves et al. (2016), Lane (2012), Lane and Milesi-Ferretti (2012), Reis (2013) for details of the Portuguese banking system and current account imbalances.

4. Coates and Everett (2013), Everett et al. (2015), Alves et al. (2016).

5. Kearns (2007). 
While the euro area had a broadly balanced current account, both Ireland and Portugal experienced widening deficits during the mid-2000s (Figure 1). The removal of exchange rate risk within the euro area, combined with lower liquidity risks, led to significant inflows of capital to both countries (KalemliOzcan et al. 2010). The dynamics in the patterns of savings and investment, however, differed somewhat across the two economies. Ireland experienced increased investment in the years before the last international financial crisis, a substantial component of which was due to the expansion of the construction sector. In contrast, economic growth was subdued in Portugal with both savings and investment on a declining trend.

A strong driver of the current account deficits was an increase in crossborder capital inflows to the government and banks, with the latter being of greater importance to Ireland relative to Portugal (Figures 2a and 2b). In fact, while there was considerable international leveraging by banks in both countries, it was relatively larger for Irish banks, peaking at 211 percent of GDP for Ireland at end-2008 compared to a peak of 113 percent of GDP in Portugal in early 2010. Lending to the non-financial sector increased sharply in Ireland in the mid-2000s, peaking at 171 percent of GDP at end-2009, and exceeding Portugal's peak lending of 154 percent of GDP in the first quarter of 2010 (Figure 3). ${ }^{6}$ The interaction between global banks and Irish retail banks in international financial markets provided the latter with funding to facilitate increasing domestic credit demand, and helped to fuel the Irish credit boom and housing bubble during the mid-2000s (Honohan 2006, 2009, BIS 2011, Lane and McQuade 2014, Everett 2015, Lane 2016). House prices in Ireland more than doubled between 1999 and 2007 (Figure 4). For Portugal house price growth was far more subdued and remained comparatively steady during the crisis period, experiencing only modest declines (Lourenço and Rodrigues 2015). Capital inflows to Portugal during the pre-crisis period were also dominantly channelled toward non-tradable sectors (Reis 2013, Dias et al. 2016).

While both economies witnessed a sharp contraction in the outstanding amount of gross external debt during the sovereign debt crisis period, leading to a contraction in private non-financial sector lending, the fall was far greater in Ireland than in Portugal. By end-2015 private non-financial sector lending in Ireland had fallen to 54 percent of GDP and to 117 percent of GDP in Portugal. So while both countries experienced a strong leveraging trend after the introduction of the euro and a sizeable correction after the euro sovereign debt crisis, the amplitude of the changes was greater in Ireland. The largest amplitude of the credit cycle in Ireland was accompanied by more pronounced shifts in real estate prices and in macroeconomic developments.

6. On the eve of the introduction of the euro, lending to the non-financial private sector was 61 percent and 78 percent of GDP in Ireland and Portugal, respectively. 
The Irish banking system is closely linked with those of the UK and US (Coates and Everett 2013, Everett 2015, Lane 2016). Furthermore, both Sterling and the US dollar were significant components of the foreign liabilities of Irish banks prior to 2008 (Lane 2016). In particular, the interbank market in the UK was a significant funding source for Irish banks during the leveraging up phase (Coates and Everett 2013). ${ }^{7}$ This suggests that the monetary policy of the UK and the US are important factors for financial conditions in Ireland, most notably during this pre-crisis period.

The Portuguese economy is substantially less open than the Irish and economic and financial integration is much stronger within the euro area than outside. Nevertheless, the UK is an important trading partner of Portugal and UK banks were present in the Portuguese financial system during most of the analysis period. Regarding the US, the link is much more likely to be related to the role of the US dollar as an international funding currency.

\section{Data}

\subsection{Data sources and sample definition}

The structure of the Irish banking system is complex owing to the presence of an influential international financial services centre (IFSC). Banks comprising the IFSC group are predominantly global banks without activity in the domestic credit market. Furthermore, with the exception of employment and the export of financial services, their activities bear little relation to the core Irish economy. Motivated by the focus of this paper on lending to the private sector, these banks are excluded from the sample. Banks active in the domestic credit retail market comprise both domestically-owned and foreign-owned banks, the latter of which all have European parent banks. Data limitations narrow the sample of banks employed in the empirical analysis for Ireland to nine banks, five of which are Irish-owned and four of which have foreign parent banks. The small sample size should thus be something to bear in mind in the analysis of the results. However, given the concentration that characterises many banking systems around the world, the external validity is not hindered for small open economies with concentrated banking systems.

In the case of Portugal, the five largest banking groups accounted for around three quarters of bank credit to non-financial residents. One of these five groups is part of a large foreign banking group. The rest of the Portuguese banking system comprises many small and medium-sized banks. Most of these banks are universal banks, competing directly with the five largest banking groups. A few

7. On average non-affiliated banks in the UK accounted for 40 percent of total foreign funding between 2002 and 2008 (Coates and Everett, 2013). 
of them have specialised business models, offering only specific products such as consumer loans or asset management services. By ownership nationality, Spanish banks dominate the market with a weight in the total credit granted by foreign banks of more than $65 \%$ over the period under analysis. The other countries with a non-negligible presence in the Portuguese credit market are the United Kingdom, Germany, and France. The sample of banks employed in the empirical analysis for Portugal includes 67 banks (approximately half domestic).

In Portugal, as in Ireland, financial institutions that operate in international financial services centres were excluded, as their activity is not lending to the real economy. Banks with less than two years of data were also not included.

For Ireland, individual bank balance sheet and flow data are drawn from data collected for the construction of the Euro Area Monetary Financial Statistics. Attributes collected from this data source include domestic loans, liquid assets, core deposits, internal capital market positions, and total assets. Despite a number of bank mergers taking place during the period under review, affected banks continued to report their balance sheets on an individual bank basis, thereby, negating the effect of these mergers on our dataset. The Tier1 data are sourced from SNL Financial and refer to consolidated data.

Most of the data on the Portuguese banks' characteristics are collected from quarterly supervisory reports at solo basis. The use of solo basis is consistent with the type of data used for Ireland. Additionally, it allows us to focus the analysis on the effect of foreign monetary policy on credit granted in Portugal, instead of also including credit granted by Portuguese affiliates abroad. Further, if consolidated data were used, all bank controls would refer to this larger perimeter of activity. To obtain data on assets and liabilities of Portuguese banks against the banks of the same banking group located abroad, the banklevel data collected for the construction of the Euro Area Monetary Financial Statistics are used.

For Ireland the data sample commences in 2000Q1. There are some methodological breaks in 2003. Prior to 2003 private sector credit data are limited to lending to the private non-bank non-government sector, thereby including lending to non-bank financial intermediaries. Furthermore, before 2003 the data are not adjusted for exchange rate effects, securitisation, and debt write-offs. These are important factors to account for in light of the securitisation activities during the mid-2000s and loan transfers to Ireland's "bad bank" during the crisis period.

The sample period in Portugal begins in 2006Q1 (a few years later than for Ireland due to data availability constraints). Using a longer period would include important breaks in some series, which are hard to address without compromising the quality of the data. Furthermore, the quality of analysis could also be compromised if many more years were included, as the beginning of that decade was dominated by a merger wave that substantially changed the landscape in the Portuguese financial system (for details, please see Barros 
et al. 2014). In both countries the last period in the dataset is 2015Q4 (64 quarters of data for Ireland and 40 quarters for Portugal).

In order to have data on the cross-border activity of banks, in both countries the bank data described above are merged with the bank-level data underlying the International Banking Statistics reported to the BIS (on a locational basis and on a first counterpart basis).

The monetary policy changes in UK and US were obtained from a database with monetary policy indicators in the main economies prepared for this project (Buch et al. 2018). The motivation for the type of monetary policy measures used in this paper is explained in Section 4.

\subsection{Variables definition}

The dependent variable is changes in lending at domestic level $\triangle Y_{b, t}$. It is defined as the change in loans granted by each bank (bank $b$ ) to non-financial residents in Ireland or Portugal in each quarter $(t)$, measured in log percentage points.

The bank-level explanatory variables considered in our specifications are: size, measured by the log of total bank assets, the Tier 1 ratio (leverage ratio, in the case of Portugal $^{8}$ ), the liquid assets ratio (defined as cash and liquid securities as a percentage of total assets ${ }^{9}$ ), the percentage of the bank's net external intragroup funding relative total assets, and the percentage of the bank's balance sheet financed with core deposits. A summary of the definitions of the bank-level variables employed in the empirical analysis is reported in Appendix 1. Buch et al. (2018) describe in detail the rationale behind each explanatory variable considered.

Table 1 summarises these indicators for the full sample period in Ireland (Table 1a) and Portugal (Table 1b). The comparison of these tables reveals some of the main differences between Irish and Portuguese sample of banks. There are more banks in the Portuguese banking system, but more total assets in the banking system in Ireland. In both cases, slightly more than half of the banks are foreign. This might enhance the cross-border transmission of monetary policy into these countries. On average, loans were growing more in Ireland than in Portugal during the sample period.

The cross-border transmission of monetary policy is assessed by looking at banks' dimensions. The channels considered include cross-border exposures

8. Using the leverage ratio instead of the Tier 1 ratio warrants that branches of EU banks are not excluded from the analysis, as these institutions are exempt from satisfying capital requirements at host countries. These institutions play a role for the analysis of the crossborder transmission of monetary policy and are thus included in the sample. When we explore the role of banks' capital as a friction in the transmission mechanism, we consider explicitly the Tier 1 ratio, leading to a reduction in the number of observations in these regressions.

9. For Portugal the definition is slightly adapted, due to data availability constraints, as detailed in Appendix 1. 
that Irish and Portuguese banks hold vis-à-vis the US and the UK (countries from which we are assessing the inward transmission of monetary policy), as well as some bank characteristics that capture asset composition and balance sheet structure. The motivation for the analysis of these channels is discussed in Section 4.

The variables measuring the exposure of the Irish and Portuguese banks to UK and US are: cross-border liabilities, net cross-border liabilities, cross-border assets, cross border-assets to banks, and cross-border assets to non-banks. All the variables are scaled by each bank's total assets. Tables $2 \mathrm{a}$ and $2 \mathrm{~b}$ include some statistics for these variables for Ireland and Portugal, respectively. These data show that Irish banks are more linked to the UK and the US financial system than Portuguese banks. Both countries are more exposed to the UK than to the US.

Finally, in order to ensure that our results are anchored in good quality data, we impose some filters on the data. Observations for which the quarterly change of credit was above $100 \%$, in absolute terms, are dropped (this entails dropping 36 observations in Portugal and 17 in Ireland). All bank and channel variables are winsorized at the 1st and 99th percentiles. Finally, we made sure that all variables defined as ratios varied between 0 and $100 \%$.

\section{Empirical approach}

To investigate the influence of US and UK monetary policy on domestic lending to the non-financial sectors in Ireland and Portugal, the empirical approach is similar to that described in Buch et al. (2018), where the methodology underlying this internationally coordinated research project is presented in greater detail. The main empirical specification is as follows:

$$
\begin{aligned}
& \triangle Y_{b, t}=\alpha_{0}+\sum_{c t r y}\left(\sum_{k=0}^{K}\left(\alpha_{1, k}^{c t r y} \cdot \triangle M P_{t-k}^{c t r y} \cdot \text { Channel }_{b, t-K-1}^{c t r y}\right)+\right. \\
& \left.\alpha_{2}^{\text {ctry }} \text {.Channel } \text { Ch,t-K-1}_{b-1}^{\text {ctry }}\right)+\alpha_{3} \cdot X_{b, t-1}+f_{b}+f_{t}+\varepsilon_{b, t}
\end{aligned}
$$

where $\triangle Y$ is the growth of lending to the non-financial sector by bank $b$ at time $t$.

The measure of foreign monetary policy is denoted by $\triangle M P$, where the index ctry represents the US and the UK. $\triangle M P$ enters the regression contemporaneously, in addition to the three quarters before $(K=3)$, in order to take into account the lags in the transmission of mechanism of monetary policy. Given that our sample period includes many years during which central banks adopted unconventional monetary policy measures, the short-term interest rate does not adequately capture the stance of monetary policy throughout the whole period. Likewise, capturing monetary policy using proxies such as 
the size of central bank balance sheets poorly portrays monetary policy in a conventional monetary policy setting. Therefore, our preferred measure of the monetary policy stance is a shadow interest rate as measured by Krippner (2016). The shadow rate allows for bridging the differences between monetary policy in conventional and unconventional periods, offering a consistent measure of the effective level of monetary policy interest rates during the whole sample period under review.

Furthermore, for the full sample period analysis, we use as an alternative measure of the monetary policy the residuals of a Taylor rule estimated on the short rate. This measure accounts for movements in the monetary policy stance that are not related to business cycles in the UK and US (i.e., it captures whether interest rates are above or below what should be expected given developments in prices and growth). The Taylor-residual is potentially more related with monetary policy "surprises" than the shadow rate. Thus, we do not expect the results obtained with the two measures to be entirely consistent.

Channel represents a range of mechanisms or frictions through which shifts in foreign monetary policy can be transmitted through banks in Ireland and Portugal. We consider two types of frictions: funding and portfolio frictions.

Funding frictions, which are more directly related to the traditional literature on the bank lending channel, include: (net and gross) cross-border liabilities against the country where the monetary policy change occurred and liquid assets. These channels or frictions might amplify or mitigate the baseline transmission mechanism. For instance, banks with average greater funding (gross and net) abroad are likely to be relatively more affected by a tightening in monetary policy if they cannot substitute those funding sources. The liquidity of banks is also considered, as relatively more liquid banks are likely to be able to offset the monetary policy induced fall in foreign funding by drawing on their more liquid assets to continue their lending activity to the private non-financial sector in their domestic economy.

Portfolio frictions relate to the fact that the transmission mechanism might work differently depending on the choices made by banks in terms of asset composition. A tightening of monetary policy abroad might lead to a decrease in the value of assets in that country. Domestic banks with greater exposures to those assets suffer a negative shock, which can lead to a decrease in lending at home. However, if these banks have a more flexible structure of assets, they might be induced to reallocate their portfolios away from these countries and increase domestic lending, given the perceived deterioration in foreign borrowers' creditworthiness due to higher interest rates.

To explore this, we consider the Tier 1 ratio, commercial and industrial loans $(\mathrm{C} \& \mathrm{I})$, securities and cross-border asset holdings to the country that is the source of the monetary policy shock (split by exposures to the banking 
sector and to others). ${ }^{10}$ Better capitalised banks are better able to insulate themselves from adverse shocks. Based on this, we would expect to obtain a positive coefficient associated with the Tier 1 ratio after a tightening in the monetary policy abroad. The C\&I lending captures the degree to which a bank focuses on lending to the real domestic economy and could thus benefit less from an increase in asset prices abroad. Therefore, the higher the share of C\&I lending, the smaller the effect on domestic credit due to a tightening in foreign monetary policy (positive signal).

On the other hand, there might be an amplification mechanism (negative signal), coming from a portfolio rebalancing effect. Securities can be expected to have a positive coefficient due to their higher liquidity, which increases the ability of banks to rebalance their assets structure between domestic and foreign assets. On the other hand, the higher sensitivity of securities holdings to interest rates changes might amplify the effect of monetary policy changes (Bernanke and Gertler 1995). The variables that measure the weights of the asset holdings to UK and US can also act as either a mitigating or an amplifying mechanism of the monetary policy shock. In fact, after an increase in the foreign asset values induced by a loosening of monetary policy, banks with larger foreign exposures might either grant more credit domestically or reallocate more resources abroad.

To ensure that the channel variables are not affected by changes in monetary policy, they enter the regressions with a lag of four quarters, given that we consider the effects of monetary policy on lending growth from $t$ to $t-3$.

$X_{b}$ is a vector of bank-specific time varying characteristics included to capture heterogeneous developments across the balance sheets of banks. As mentioned in Section 3.2, the banks' characteristics included are: the log of total assets, Tier 1 capital ratio (or the leverage ratio in the case of Portugal), liquid assets ratio, net internal group funding ratio, and core deposits ratio.

To account for time-invariant bank-specific unobservable factors (e.g. risk appetite, business model, or balance sheet management strategy) bank fixed effects, $f_{b}$, are included. Time fixed effects, $f_{t}$, are included to control for common global and domestic factors, including domestic monetary policy. Finally, $\varepsilon_{b, t}$ is the error term and is clustered at the bank level.

In a second part of our analysis we distinguish between the pre-crisis and crisis periods. We split the sample in two, whereby the pre-crisis period is defined up to 2010Q2, and the crisis period is considered to be 2010Q3 to 2015Q4. The motivation underlying the choice of mid-2010 as the break between the two periods is related to the Greek request for financial assistance in April 2010, following which the crisis spread to Ireland and Portugal. This implied considerable changes in the financial market functioning, the role of central

10. All these variables, except the Tier 1 ratio, are scaled by total assets. 
banks, and the set of instruments used in the definition of monetary policy in the euro area.

\section{Results}

In this section we present the results of our empirical analysis. First, in Section 5.1 we describe the cross-border transmission of monetary policy for Ireland and Portugal during the entire sample period. The empirical analysis for both economies focuses on the inward transmission of monetary policy in two major economies, UK and US, exploring several dimensions of banks' balance sheets that may play a role in the pass-through of monetary policies across borders. We anchor our analysis around two types of frictions: funding frictions and portfolio frictions. As discussed above, given the challenges in adequately capturing the stance of monetary policy, most notably when unconventional monetary policy measures are adopted, shadow interest rates and Taylor residuals are employed.

Second, in Section 5.2 we zoom in on the crisis period, to address our main research question: how does the transmission of monetary policy change when the financial system is severely distressed? Are there differences when the crisis is more centred on the financial system (as in Ireland) or when it results from broader structural weaknesses (as in Portugal)? To answer this we split our samples into two periods, looking at the cross-border transmission of monetary policy before and after the Spring of 2010 .

\subsection{The international transmission of monetary policy: main results}

5.1.1. Funding frictions. Table 3 reports the results for the estimation of equation (1) when we consider the role of funding frictions and capture monetary policy through the shadow rate. Three channels through which banks' funding choices might affect the way changes in monetary policy abroad influence banks' lending decisions are explored: i) cross-border liabilities with respect to the country changing monetary policy; ii) net cross-border liabilities (also at the country level); and iii) liquid assets. All channels are scaled by banks' total assets.

Regarding the first two channels, we expect that the lending policy of banks that borrow more intensively from the countries in which the monetary policy shocks originate reacts more intensively than the lending policy of those banks with smaller exposures or none at all. These two channels should thus work as an amplification mechanism of the cross-border shocks. On the contrary, banks that have a larger buffer of liquid assets may be more insulated from these shocks, as they have more leeway to manage and accommodate short-term shocks to funding costs. 
Columns (1) to (3) report the results for the three channels for Ireland, while columns (4) to (6) report the results for Portugal.

For simplicity, we report only the results that capture the impact of monetary policy. ${ }^{11}$ We consider changes in monetary policy in the US and UK, two major economies with links to Ireland and Portugal. Changes in the euro area (domestic) monetary policy are captured through time fixed effects.

The first two rows of Table 3 report the estimated effect of changes in US and UK monetary policy, respectively, through each of the different channels. This corresponds to the sum of the coefficients $\alpha_{1, k}^{c t r y}$ associated with the interaction between monetary policy changes from $t$ to $t-3$ in these two countries and the four-quarter lag of the channel considered. Then, below the line we report the sum of the contemporaneous effect of monetary policy in the US and in the UK, interacted with the channel under analysis. This allows us to measure the immediate cross-border impact of monetary policy on bank lending. Finally, we report the sum of all the eight coefficients associated with the interaction between monetary policy and each channel (four interaction terms for each country).

The results reported in Table 3 suggest that, for the whole period, the cross-border transmission of monetary policy is rather contained, in both Ireland and Portugal. For Irish banks there is only one (marginally) statistically significant result. Following a tightening of US monetary policy, Irish banks that have more net cross-border liabilities sourced from the US lend less to Irish borrowers. This works in the expected way, as banks that are more exposed to the shock react more intensely. For Portuguese banks there is also a marginally statistically significant result for this channel, but coming only from the UK. The direction of this relationship is, however, the opposite of what would be expected: when the Bank of England tightens monetary policy, banks that obtain more net cross-border funding in the UK actually lend more to Portuguese borrowers. For liquid assets the results are nevertheless in line with expectations: when monetary policy becomes tighter abroad, Portuguese banks with more liquid assets are better insulated from that shock and are able to lend more domestically. This last result comes from the joint effect of all the coefficients associated with the interaction between monetary policy and liquid assets.

In Table 4 we report similar results, but now considering Taylor residuals instead of shadow rates. The results become stronger when monetary policy stance is captured in this way, most notably for Portugal.

For Irish banks we obtain the expected positive coefficient associated with liquid assets for UK's monetary policy. When monetary policy tightens, banks with more liquidity are better equipped to face that shock and continue lending.

11. The remaining coefficients resulting from the estimation of equation (1) are not reported, but are available upon request. 
However, this effect seems to be cancelled out by a negative effect coming from US monetary policy, as the joint effect of monetary policy is not significant. For the other two channels capturing cross-border liabilities, there are no significant results found for Irish banks.

For Portuguese banks the positive coefficients obtained with net crossborder liabilities in Table 3 are reinforced in this set-up. When we consider Taylor residuals instead of the shadow rate, this effect becomes significant not only in the UK, but also in the US (and actually with greater economic and statistical significance). The expected positive coefficient for liquid assets also becomes more important, though there is a negative effect coming out from the UK's monetary policy.

Across the board, the results concerning funding frictions are relatively weak. The results have the expected sign for the liquid asset channel, especially for Portugal. Albeit in a less consistent way, the results are also in line with expectation for the net cross-border liabilities channel for Ireland. The remaining results are either non-significant or work in a direction that is not in line with expectations.

5.1.2. Portfolio frictions. The cross-border transmission of monetary policy may be shaped not only by banks' funding structures, but also by their previous portfolio decisions. In Table 5 we present the results on the cross-border transmission of shadow rates for the different channels described in Section 4.

The first channel captures how differences in banks' Tier 1 capital ratios influence the transmission of monetary policy. When we examine the results reported in columns (1) and (6), for Ireland and Portugal, respectively, we find only a marginally statistically significant positive coefficient for the effect of US monetary policy on bank lending in Portugal. However, the effect of UK monetary policy has the opposite sign, cancelling out this effect. For Ireland, we obtain a counterintuitive negative aggregate coefficient, suggesting that when monetary policy becomes tighter, banks with more capital actually lend less than other banks.

The second variable considered is commercial and industrial (C\&I) loans as a percentage of total assets. For Irish banks we do not find any statistically significant evidence that this channel is at work. For Portuguese banks there is an aggregate negative effect stemming from the US monetary policy (as the effect coming from the UK is actually positive). The negative coefficient shows that when foreign monetary policy tightens, banks that are more specialised in C\&I lending transmit this credit supply shock to domestic borrowers more actively, thus acting as an amplification factor.

The third channel seeks to capture another dimension of bank specialisation. By looking at securities as a percentage of total assets, we also find that Portuguese banks more exposed to these assets lend less when interest rates 
increase abroad. ${ }^{12}$ Interestingly, this result is at odds with that obtained for liquid assets (the last column of Table 3), as well as with the results obtained by Kashyap and Stein (2000) on the domestic transmission of US monetary policy. One possible explanation for the negative coefficient might be the fact that the sensitivity of securities prices to monetary policy changes dominates the mitigating effect associated with their higher liquidity.

In the fourth channel analysed we examine how monetary policy is transmitted across borders depending on how large banks' exposures, in terms of assets, are to the US or the UK. We find that having a larger exposure in terms of total assets to the countries where monetary policy is being tightened actually leads to more lending in Ireland. This channel acts as a mitigating rather than an amplifying mechanism. The effect comes from both the UK and the US monetary policy, and it seems to come mainly from assets to non-banks, though both types of exposures play a role. For Portugal the transmission through banks' foreign assets exposures does not seem to operate.

In Table 6 we replicate our analysis of portfolio frictions for Taylor residuals. The results are substantially different, showing that the way monetary policy is measured may lead to important differences in the conclusions obtained. Regarding the first channel considered - the Tier 1 ratio - none of the significant results obtained with shadow rates remains valid. Based on a Taylor rule, banks' capitalisation does not seem to play a role in how monetary policy is transmitted across borders.

For C\&I loans, the results are more similar to those obtained with the shadow rate. This friction still does not play a role for Irish banks, while for Portuguese banks it continues to offer an amplification mechanism, making banks that are more exposed to these assets more sensitive in their lending decisions to foreign monetary policy shocks. The securities channel in Portugal is not significant with the Taylor residual, while it was when shadow rates were considered.

The most noticeable differences are perhaps seen when looking at crossborder assets. For Irish banks the mitigating role associated with these assets documented in Table 5 vanishes when we consider Taylor residuals. If anything, there is a temporary immediate amplifying mechanism associated with assets to foreign banks. For Portugal, an amplifying mechanism of the cross-border assets is also found in this set-up, while these variables did not play any role when shadow rates were considered. When Portuguese banks hold more assets vis-à-vis the UK (most notably assets of banks), a tightening of monetary policy is associated with less lending domestically. The differing results obtained with the two measures of monetary policy might not be surprising given that asset prices reactions are mainly determined by unexpected events, which are more related with the Taylor residual than with the shadow rate.

12. Due to data availability constraints, it is not possible to estimate this channel for Ireland. 
In summary, the empirical analysis shows that some portfolio decisions of banks work as frictions for the cross-border transmission of monetary policy, either as amplification or mitigation mechanisms. The results vary depending on the monetary policy measure used and are also quite different for Portugal and Ireland.

\subsection{The international transmission of monetary policy: zooming in on the crisis}

The analysis of the cross-border transmission of monetary policy during our sample period entails important challenges. Major central banks of global systemic importance adopted an unprecedented toolkit of unconventional monetary policy measures and at the same time financial instability might affect the transmission of monetary policy. The first challenge is detailed in Buch et al. (2018) and the use of shadow interest rates in the empirical analysis is an attempt to address this issue. On the second challenge, Ireland and Portugal offer an interesting setting to examine how bank distress affects the crossborder transmission of monetary policy. Both countries underwent a period of profound adjustment during the euro area sovereign debt crisis, and were in the spotlight during this period. The origins and the development of the crisis share similarities, but also have important differences. It is therefore interesting to dig deeper into the cross-border transmission of monetary policy during the euro area sovereign debt crisis.

To investigate this further, we re-estimate our regressions in two separate periods: a pre-crisis period going up to 2010Q2, and a crisis period going from 2010Q3 to 2015Q4. The dividing line for the sample split is thus the Greek request for international financial assistance in April 2010, which paved the way for a substantial deterioration of funding conditions in both Ireland and Portugal, ultimately leading to these two countries' request for international financial assistance. We replicate our previous analysis on funding and portfolio frictions using the shadow interest rate to capture monetary policy. ${ }^{13}$ Before doing that, we summarise some of the main features of the crises in Ireland and Portugal, as well as the vulnerabilities leading up to both of them. Understanding the commonalities and differences is crucial for the interpretation of the results.

5.2.1. The euro area sovereign debt crisis in Ireland and Portugal. Although the euro area experienced negative spillovers from the global financial crisis, at its early stages there was no discernible widening in the differentiation of

13. In this part of the paper we abstain from using Taylor residuals, given that a theoretical policy rule could have suffered structural breaks between the pre-crisis and the crisis environment. In contrast, shadow rates are designed specifically to bridge periods in which monetary policy is being implemented in different ways. 
sovereign spreads of euro area countries. As the global financial crisis intensified in the wake of the collapse of Lehman Brothers, a reassessment of risk by financial market participants meant that risk perceptions became associated with individual countries, particularly those with macroeconomic imbalances (Barbosa and Costa 2010).

The intensified turbulence in the interbank market in Autumn 2008, exacerbated the perceived underlying weakness in the Irish banking system, with Irish banks finding it increasingly difficult to roll over international wholesale funding. These developments, along with a shortage of collateral needed to obtain monetary authority funding, culminated in the Irish Government's guarantee of Irish-owned banks' liabilities on 30 September 2008 (Honohan 2009). ${ }^{14}$ Anglo Irish Bank was nationalised in January 2009, which further highlighted the tightening of the feedback loop between banks and sovereigns.

Financial strains in the euro area escalated into a crisis following the request of Greece in April 2010 for international financial assistance, when financial markets turned to the increasingly unsustainable macroeconomic imbalances amongst the group of euro area countries, compounded by the increasingly tight nexus between sovereigns and banks.

As the expiration of the original Irish Government guarantee approached, greater than anticipated banks' loan losses led to additional capital requirements for banks (Honohan 2012). This was compounded by increased reliance on central bank funding from Autumn 2010 on, due to the inability of Irish banks to raise funds to replace maturing debt that had been guaranteed in September 2008. This factor, combined with the deteriorating conditions of the Irish fiscal balance sheet, ultimately led to Ireland's entry into the EU/IMF Financial Measures Programme in December 2010. ${ }^{15}$

Even though Portuguese banks had in the beginning of the financial crisis remained reasonably insulated from the shock waves coming from the failure of Lehman Brothers, beginning in Spring 2010 Portugal attracted the attention of international investors, who became visibly more worried about the structural weaknesses of the Portuguese economy. This led to a sudden loss of access of the sovereign and of banks to international wholesale debt markets, which was compensated for with access to central bank funding (Alves et al. 2016).

By Spring 2011 Portuguese banks were entirely dependent on access to ECB funding. The soaring sovereign bond yields and the consecutive downgrades of

14. Credit Institutions (Financial Support) Act 2008 was a blanket guarantee of the six Irish-owned banks' deposits and covered debt securities between 30 September 2008 and 29 September 2010. Irish-owned banks included Allied Irish Banks PLC, Bank of Ireland, Irish Bank Resolution Corporation (until liquidation in February 2013), EBS Building Society, Irish Life and Permanent PLC, Irish Nationwide Building Society, and their subsidiaries.

15. European developments at this time also played a key role (including the announcement of the Deauville Agreement). 
bank and sovereign ratings precipitated the request for international financial assistance in April 2011. The programme shared many similarities with that of the Irish. Its milestones aimed to foster the adjustment of the financial system, a gradual and orderly deleveraging of the non-financial sector, and included measures to address other structural weaknesses in the Portuguese economy (namely by bringing structural reforms and promoting fiscal consolidation).

Both countries successfully exited the programme: Ireland in late 2013 and Portugal in the Spring of 2014. However, the recovery paths of the economies and financial systems have been quite different. The Irish economy began to recover immediately after the crisis and banks are on a broadly stable path. In contrast, growth in the Portuguese economy was modest in the first years after the programme. Two large banks have been put under resolution since then and some concerns remain about legacy troubled assets in banks' balance sheets.

How did this challenging period affect the cross-border transmission of monetary policy in the two economies? We provide evidence on this by contrasting the transmission mechanisms existing before the sovereign debt euro area crisis with those observed during the crisis. There is ample evidence that monetary policy transmission within borders is severely impaired when banks are distressed (Ciccarelli et al. 2013). We complement this literature by looking at the cross-border transmission mechanisms during a crisis period. Overall, reduced reliance on international investors for funding by banks in Ireland and Portugal would suggest that the channels through which we expect foreign monetary policy to affect domestic lending are no longer as strong during the crisis period relative to the pre-crisis period. In the next subsections we present evidence to test this hypothesis.

5.2.2. Funding frictions. In Table 7 we report the results concerning funding frictions for Ireland and Portugal (left and right panels, respectively), before and after the start of the sovereign debt euro area crisis (top and bottom panels, respectively).

When we compare these results with those reported in Table 3 for the entire sample period, the differences are striking. The results become generally much stronger for both countries. This suggests that imposing the same specification throughout such a heterogeneous period might disguise important differences in the cross-border transmission of monetary policy.

Regarding the first funding friction considered, cross-border liabilities from the UK and the US, we had found that this channel did not play any role in the transmission of foreign monetary policy when the entire sample period is considered. This is clearly not the case when we consider the two periods separately. Before the crisis, banks that obtained more funding in countries where monetary policy was tightened had contractionary effects on domestic bank lending. The effect is visible for both countries and is especially stronger for Portugal, where changes in US monetary policy dominate. After the start of 
the euro area sovereign debt crisis, the results are not as clear. For Irish banks, the sign is reversed and it becomes weaker. For Portuguese banks, cross-border liabilities still work as an amplification factor, but only in the short-run impact, i.e. the effects are much more short-lived. Further, the effect coming from the US also becomes positive, as seen for the effect of the UK's policy on Ireland.

When we consider net (instead of gross) cross-border liabilities the results also become stronger when the two periods are estimated separately. Before the crisis net cross-border liabilities vis-à-vis the countries changing their monetary policy generally act as an amplification mechanism. The results are again stronger for Portuguese banks. ${ }^{16}$ After the crisis this friction seems to be slightly weaker. However, now its cumulative effects have the opposite direction for Portugal: banks that are more exposed to a tightening actually lend more. For Ireland the results are similar but only significant for the short-run effect.

Finally, holdings of liquid assets also have different implications in the two periods considered. The mitigating effect documented in Table 3 for Portuguese banks is now also visible in Ireland in the pre-crisis period. However, this friction entirely loses all importance during the crisis. This might be related to the massive central bank interventions, which offered ample liquidity to banks, thereby rendering their ex-ante choices in terms of liquidity irrelevant for the cross-border transmission of monetary policy. In general, the stronger evidence found in favour of the funding frictions before the crisis is in line with the expectations that these frictions grew less important with unconventional monetary policy.

5.2.3. Portfolio frictions. Table 8 reports the results for portfolio frictions in the two sub-periods analysed. An initial inspection of the table shows an interesting pattern: while portfolio frictions do not play any role in Ireland before the crisis (top left panel), they do not play any role in Portugal after the start of the crisis (bottom right panel). In other words, the asset structure of banks before the crisis is irrelevant for the cross-border transmission of monetary policy for Irish banks before the crisis and for Portuguese banks during the crisis. One tentative explanation for this might be that before the crisis the overheating environment experienced in Ireland made these frictions irrelevant, with monetary policy transmitted homogeneously through banks with different characteristics. During the crisis these characteristics play a comparatively more important role. For Portugal, the opposite seems to hold. Before the crisis banks' portfolio decisions interact with the cross-border transmission of monetary policy, but during the crisis the impact on lending does not seem to be affected by the asset structure of banks. Possibly the ample liquidity offered by the ECB during this period made bank heterogeneity less

16. However, for the UK the sign of the coefficient is positive. The generally weaker results for Ireland might be related to lower cross-sectional heterogeneity. 
important in Portugal. Crucially, the differences between Portuguese and Irish banks might reflect the origins of the crisis, as described in Section 2. While in Ireland there was a considerable buildup of risks in the banking system, amidst a housing bubble and an overheating of some sectors of the economy, in Portugal the origin of the crisis was much more related to macroeconomic and fiscal structural vulnerabilities. Another important difference is the relatively faster recovery trajectory of the Irish economy in the post-crisis period.

Digging deeper into the results, we can find important differences in the frictions at work in both countries. Table 5 persuades us that for Irish banks the channels or frictions related with cross-border assets were more important than banks' specialisation or capital structure. Cross-border assets to nonbanks remain notable frictions after the start of the crisis, but their sign is the opposite of what was found for the whole sample period. These exposures now have a reinforcing mechanism: banks that hold more assets of the nonfinancial sector in countries facing a monetary policy tightening now lend less domestically. For UK monetary policy, however, the effect associated with direct exposures toward banks continues to be positive.

In turn, for Portuguese banks the results in the pre-crisis period also differ along some dimensions from those obtained for the entire sample period. For Tier 1 ratio, the amplification effect associated with UK monetary policy persists, and it seems to dominate, at least in the short-term impact. For banks more specialised in C\&I loans, the results are now more consistent, revealing a robust amplifying mechanism. The opposite holds for banks with more securities on their balance sheet. While earlier the amplification mechanism dominated the results, now there is a general mitigating effect. Banks that hold more securities are able to mitigate loan contraction when monetary policy tightens abroad, which becomes consistent with the results obtained by Kashyap and Stein (2000) for the US. Finally, regarding cross-border assets, the results are still much weaker than those observed (during the crisis) for Ireland, although assets of foreign banks now play an important role. Banks that were more exposed to foreign bank assets, most notably those of the US, were better able to mitigate the effects of a tightening of monetary policy on domestic bank lending, possibly though the rebalancing of exposures away from foreign assets.

\section{Discussion of results}

In the first part of the analysis, which examines the cross-border transmission of monetary policy across both pre-crisis and crisis periods, we find that the US and UK monetary policies influence lending decisions both in Ireland and Portugal, though the mechanisms through which this occurs differ. The results concerning the role of funding frictions in the transmission of monetary policy abroad are relatively weak for both countries. The heterogeneity of funding 
conditions throughout the sample period may help to explain this. When we use a shadow interest rate to capture monetary policy, the results have the expected sign for the liquid asset channel for Ireland and especially for Portugal. Even so, in a less consistent way, the results are also in line with expectation for the net cross-border liabilities channel for Ireland. The remaining results are either non-significant or work in a direction that is not in line with expectations.

In turn, the portfolio decisions of banks amplify or mitigate the cross-border transmission of monetary policy abroad. The results vary depending on the monetary policy measure used and are quite different for Ireland and Portugal. Bank capital acts as an amplification mechanism for Ireland, while C\&I loans and securities have a similar effect for Portugal. This means that a tightening of monetary policy abroad leads to a steeper contraction in lending for the banks in which these variables are larger. In contrast, exposures through cross-border assets exert a mitigating role for Irish banks.

These aggregate results may hide important differences in the cross-border transmission of monetary policy in normal and crisis times, however. On the one hand, the design and implementation of monetary policy moved to a different paradigm during the crisis, with central banks adopting an unprecedented set of unconventional monetary policy tools. On the other hand, Ireland and Portugal were at the heart of the euro area sovereign debt crisis, though for different reasons. In the second part of the paper we therefore look separately at the precrisis and crisis periods, dividing the sample at the date of the Greek request for international financial assistance.

We find that funding frictions in the transmission of monetary policy abroad are present for both economies prior to the euro area sovereign debt crisis, findings that are consistent with expectations given the significant international borrowing by banks at this time. ${ }^{17}$ Furthermore, in this period liquid assets play a mitigating role in offsetting a funding shock driven by changes in foreign monetary policy, which disappears during the sovereign debt crisis period. Significant deleveraging by both banking systems, combined with ample provision of central bank liquidity, most likely reduced the influence of the cross-border transmission of monetary policy during the crisis. ${ }^{18}$

There are important differences coming from portfolio frictions. These results possibly reflect differences in the two economies before the crisis, during the crisis and in the duration of crises. Prior to the crisis the asset structure of Irish banks is irrelevant for the cross-border transmission of monetary policy. In contrast, for Portugal during the crisis the balance sheet characteristics of banks do not play a role in transmitting monetary policy internationally.

17. Alves et al. (2016), Coates and Everett (2013), Everett (2015), Honohan (2009), Lane (2012, 2016), Lane and Milesi-Ferretti (2012), Reis (2013).

18. Alves et al. (2016), Coates and Everett (2013), Everett (2015). 
In summary, our results show that looking at a whole period marked by deep changes in the design and transmission of monetary policy, as well as on the soundness of the financial system, hides important differences in the cross-border effects of monetary policy. By looking at two countries that go through a financial crisis, sharing commonalities and differences, we find that cross-border transmission of monetary policy is affected by three key issues: i) the reliance on external funding sources, ii) domestic developments in the run up to a crisis, and iii) the recovery trajectory in the aftermath of a crisis. First, in what concerns the reliance on external funding sources, we find that when banks lose access to external funding and become dependent on central bank borrowing, foreign monetary policy stops playing a role. This reflects developments in both Ireland and Portugal. Second, domestic developments in the run up to a crisis play an important role, given the different results found for the two economies. In Ireland, an overheating of the economy and of asset prices, together with a strong motivation of Irish banks to expand lending abroad, leads to diminished responses to external developments, which is not visible in Portugal. Finally, the recovery trajectory in the aftermath of a crisis is also relevant for the cross-border transmission of monetary policy. We find that a more prolonged recovery of the economy and of the financial system affects the regular transmission of foreign monetary policy, given the impairment of transmission in Portugal after the crisis.

\section{Conclusions}

This paper analyses the inward spillovers of UK and US monetary policy on domestic lending decisions of Irish and Portuguese banks, two economies that were in the eye of the sovereign debt crisis. We find that before the crisis the funding structure of banks played a role in the international transmission of monetary policy. There is a lack of evidence on cross-border transmission of monetary policy after the crisis started, most likely related to the increased dependence of both banking systems on central bank funding. When the asset structure of banks is examined, however, we find diametrically contrasting results across the two economies. Prior to the crisis portfolio frictions were not present for Irish banks but are influential for Portuguese banks. After the crisis these channels become relevant for Ireland but lose significance for Portugal, possibly reflecting the deeper crisis experienced in Portugal as well as the prevalence of legacy assets in the banking system over a longer time.

Our paper contributes to the empirical literature by showing from a unique perspective that monetary policy is transmitted not only within but also across borders. Our contribution to the existing literature is anchored on understanding the cross-border transmission mechanisms during a crisis period. Looking in parallel at these two countries provides greater insight as to how commonalities and differences in the run-up to and during financial crises 
help to shape the influence of foreign monetary policy on domestic lending decisions. Overall, the findings of the paper shed new light on the international transmission of monetary policy for two small open economies that share a common currency. The results have direct implications for policy makers. For small economies that are members of a common currency, not only does their domestic monetary policy stance matter, but so too does that of major currencies. The cross-border spillovers of monetary policy are heterogeneous in their effects across the financial cycle and also through their transmission mechanisms, warranting surveillance by policy makers in small open economies.

\section{References}

Alves, N., D. Bonfim, and C. Soares (2016), "Surviving the perfect storm: the role of the lender of last resort", Banco de Portugal Working Paper 2016/17.

Bank for International Settlements (BIS) (2011), "Annual Report", Basel, Switzerland, available at www.bis.org.

Barros, P. B., D. Bonfim, M. Kim and N. Martins (2014), "Counterfactual analysis of bank mergers", Empirical Economics, 46(1), 361-391.

Barbosa, L. and S. Costa (2010), "Determinants of sovereign bond yield spreads in the euro area in the context of the economic and financial crisis", Banco de Portugal Working paper 22|2010

Bernanke, B. and A. S. Blinder (1988), "Is it money or credit, or both or neither? Credit, money and aggregate demand", American Economic Review, Vol.78, No. 2, pp. 435-39.

Bernanke, B. and M. Gertler (1995), "Inside the black box: The credit channel of monetary policy transmission", Journal of Economic Perspectives, Vol.9, No.1, pp. 27-48.

Blanchard, O. and P. Portugal (2017), "Boom, slump, sudden stops, recovery, and policy options. Portugal and the Euro", Portuguese Economic Journal, 16(3), 149-168.

Bruno, V. and H.S. Shin (2015), "Cross-Border Banking and Global Liquidity", Review of Economic Studies, Vol. 82, No. 2, pp. 535-564.

Buch, C., M. Bussiere, L. Goldberg, and R. Hills (2018), "International Transmission of Monetary Policy" NBER working paper 24454 http://www.nber.org/papers/w24454.

Cetorelli, N and L. Goldberg (2012), "Banking globalization and monetary transmission", Journal of Finance, Vol. 67, No.5, pp. 1811-1843.

Ciccarelli, M., A. Maddaloni, and J. L. Peydró (2013), "Heterogeneous transmission mechanism: monetary policy and financial fragility in the Eurozone", Economic Policy, 28(75), 459-512.

Coates, D. and M. Everett, (2013), "Profiling the Cross-Border Funding of the Irish Banking System", Economic Letter Series, Vol.2013, No.4, Dublin: Central Bank of Ireland. 
Correa, R, T. Paligorova, H. Sapriza, and A. Zlate (2015), "Cross-border, banking flows and monetary policy", mimeo.

Dias, D. A., C. R. Marques, and C. Richmond (2016), "Misallocation and Productivity in the Lead Up to the Eurozone Crisis", Journal of Macroeconomics, 49, 46-70.

Everett, M. (2015), "Financial Constraints and the Internationalisation of Irish Firms", Journal of the Statistical and Social Inquiry Society of Ireland, Vol. 44, pp 1-17.

Everett, M., J. Kelly and F. McCann (2015), "International Banking and Liquidity Risk Transmission: Evidence from Ireland", IMF Economic Review, Vol. 63, No. 3, pp 542-567.

Gambacorta L. and D. Marques-Ibanez (2011), "Bank lending", Economic Policy, pp. 135-182.

Hale, G. and M. Obstfeld (2014), "The Euro and the Geography of International Debt Flows", San Francisco: Federal Reserve Bank of San Francisco, Working Paper, Vol.2014, No.10.

Honohan, P. (2006), "To What Extent Has Finance Been a Driver of Ireland's Economic Success?", Dublin: Economic and Social Research Institute, Quarterly Economic Commentary, December 2006, pp. 59-72.

Honohan, P. (2009), "Resolving Ireland's Banking Crisis", The Economic and Social Review, Vol. 40, No.2, pp. 207-231.

Honohan, P. (2012), "Recapitalisation of Failed Banks: Some Lessons from the Irish Experience", Address at the 44th Annual Macro and Finance Conference, Trinity College Dublin.

Kalemli-Ozcan, S., E. Papaioannou and J.L. Peydró (2010), "What lies beneath the euro's effect on financial integration? Currency risk, legal harmonization, or trade?", Journal of International Economics, 81(1), 75-88.

Kashyap, A. and J. Stein (1995), "The impact of monetary policy on bank balance sheets", Carnegie-Rochester Conference Series on Public Policy, 42, 151-195.

Kashyap, A. and J. Stein (2000), "What Do a Million Observations on Banks Say About the Transmission of Monetary Policy?", American Economic Review, 90(3), 407-428.

Kearns, A. (2007), "A financial stability perspective on Irish banks' foreign business", Central Bank of Ireland, Financial Stability Report 2007.

Kearns, J. and N. Patel (2016), "Does the financial channel of exchange rates offset the trade channel?" BIS Quarterly Review, December.

Krippner, Leo (2016), "Documentation for measures of monetary policy", mimeo, Reserve Bank of New Zealand, 13 July.

Lane, P. (2012), "The European Sovereign Debt Crisis", Journal of Economic Perspectives, 26(3), 49-68.

Lane, P. (2016), "The Funding of the Irish Domestic Banking System During the Boom," Journal of the Statistical and Social Inquiry Society of Ireland, XLIV, 40-68. 
Lane, P. and P. McQuade (2014), "Domestic Credit Growth and International Capital Flows", The Scandinavian Journal of Economics, Vol. 116, No.1, pp.218-252.

Lane, P. and G. M. Milesi-Ferretti (2012), "External adjustment and the global crisis", Journal of International Economics, 88, 252-265.

Lourenço, R. and P. M. M. Rodrigues (2015), "House prices: bubbles, exuberance or something else? Evidence from euro area countries", Banco de Portugal Working Paper 2015/17.

Reis, R. (2013), "The Portuguese Slump and Crash and the Euro Crisis", Brookings Papers on Economic Activity, 44(1), 143-210. 


\section{Figures and Tables}

Figure 1: Current account balances, percent of GDP

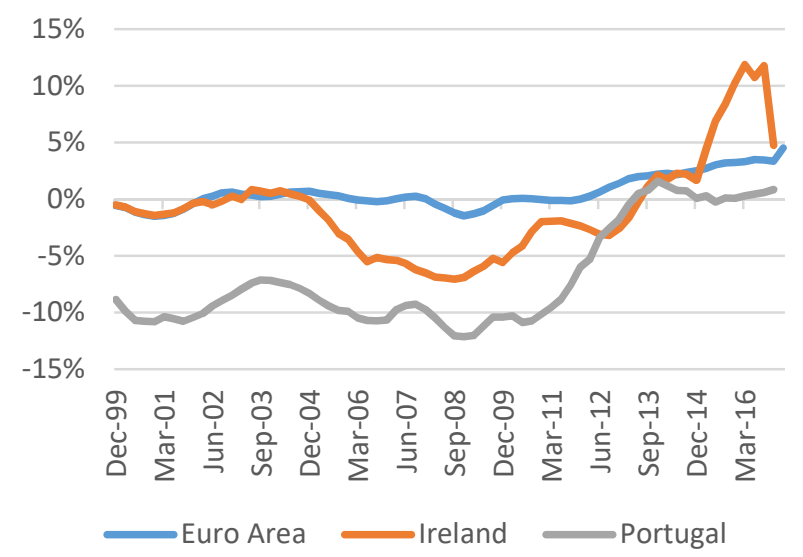

Data sources: Eurostat and ECB's SDW

Figure 2b: Gross external debt, percent of GDP, Portugal

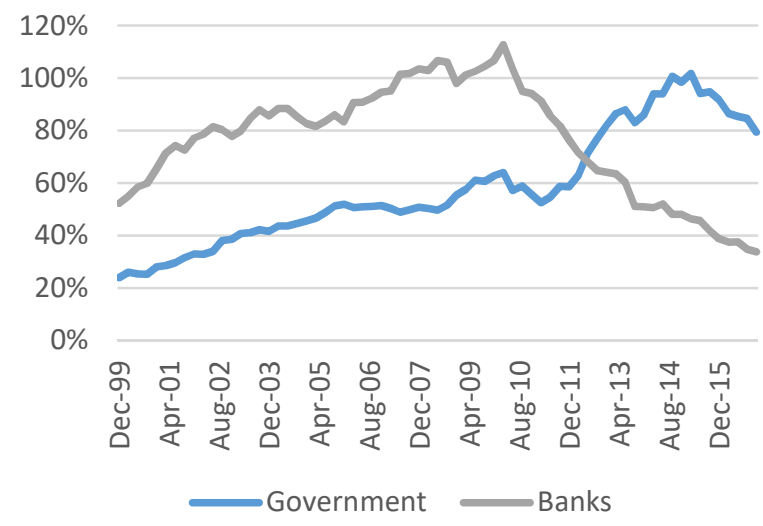

Data source: Eurostat
Figure 2a: Gross external debt, percent of GDP, Ireland

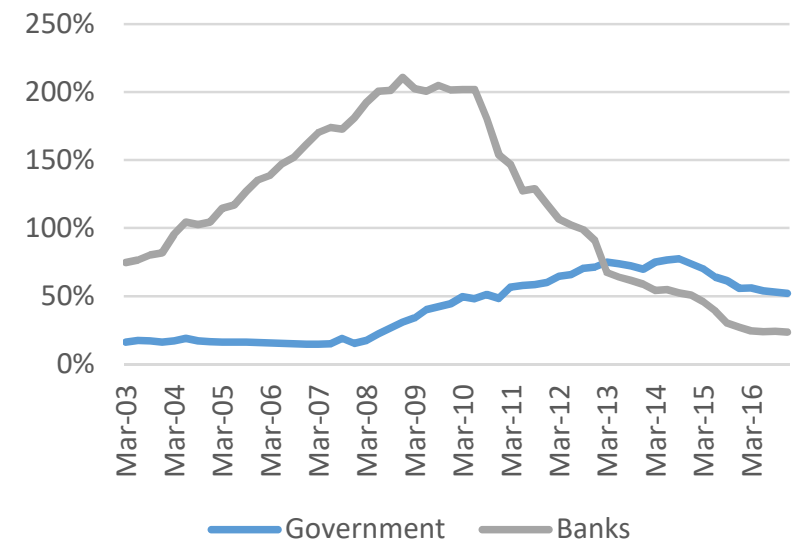

Data source: Eurostat

Figure 3: Bank credit to the private nonfinancial sector as a percent of GDP

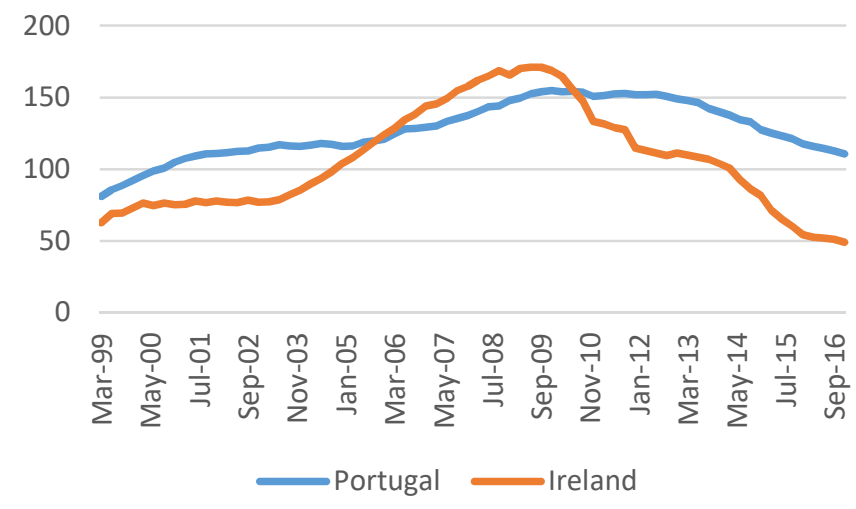

Data source: BIS Credit to the non-financial sector database 
Figure 4: Residential property price indices

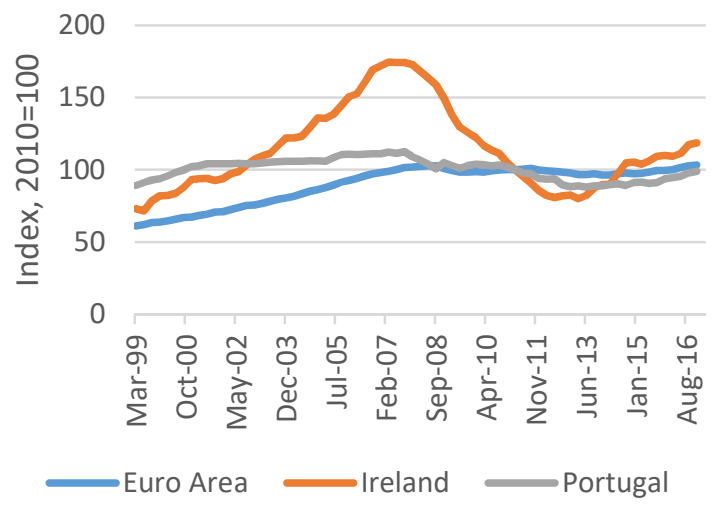

Data source: BIS

Table 1a (Ireland): Summary Statistics on Bank Lending and Characteristics

Panel of retail resident banks with foreign exposures, including subsidiaries and excluding branches. Period: 2000Q1-2015Q4.

\begin{tabular}{|lcccc|}
\hline \multicolumn{1}{|c}{ Variable } & Mean & SD & Min & Max \\
\hline \hline General Inward Statistics & & & & \\
Total assets of the resident banking sector (USD mn) & 300,536 & 134,165 & 90,207 & 515,234 \\
Number of banks & 8 & 1 & 7 & 9 \\
Number of foreign banks & 5 & 1 & 3 & 5 \\
Total bank assets (USD mn) & 36,102 & 13,259 & 12,887 & 57,248 \\
Domestic lending (USD mn) & 18,652 & 18,000 & 0 & 82,263 \\
Loans to the domestic non-financial private sector (USD mn) & 14,579 & 12,380 & 0 & 59,295 \\
Log changes in loans to the domestic non-financial private sector & 5.5 & 19.8 & -67.7 & 100.0 \\
Transmission Channel Statistics without country dimension (ratios in \%) & & & \\
Liquid Assets / Total Assets & 2.2 & 5.2 & 0.0 & 100.0 \\
Tier 1 Ratio & 10.7 & 3.1 & 5.8 & 20.5 \\
C\&I Loans / Total Assets & 19.8 & 14.7 & 0.0 & 53.2 \\
Other Balance Sheet Controls (ratios in \%) & & & & \\
Log total assets & 23.8 & 1.4 & 15.6 & 26.1 \\
Net IG funding ratio & 5.9 & 23.2 & -99.6 & 100.0 \\
Core deposits ratio & 30.2 & 13.3 & 0.0 \\
\hline
\end{tabular}

Table 2a (Ireland): Statistics on channels and frictions

Ratios in \%. Period: 2000Q1-2015Q4.

\begin{tabular}{|lcccc|}
\hline \multicolumn{1}{|c}{ Variable (ratios in \%) } & mean & sd & mean & sd \\
\hline \hline Cross-border Liabilities from ctry/ Total Assets & 3.4 & 3.7 & 15.7 & 10.3 \\
Net Cross-border Liabilities from ctry / Total Assets & 0.4 & 3.8 & 0.5 & 10.5 \\
Cross-Border Assets in ctry / Total Assets & 3.1 & 3.7 & 15.5 & 15.5 \\
Cross-Border Assets to Banks in ctry / Total Assets & 1.2 & 1.6 & 11.5 & 14.9 \\
Cross-border Assets to Non-Banks in ctry/ Total Assets & 1.9 & 2.8 & 3.2 & 3.2 \\
\hline
\end{tabular}


Table 1b (Portugal): Summary Statistics on Bank Lending and Characteristics

Panel of all resident banks with foreign exposures, including subsidiaries and branches. Period: 2006Q1-2015Q4.

\begin{tabular}{|c|c|c|c|c|}
\hline Variable & Mean & SD & Min & $\operatorname{Max}$ \\
\hline \multicolumn{5}{|l|}{ General Inward Statistics } \\
\hline Total assets of the resident banking sector (USD mn) & 573,052 & 71,332 & 449,313 & 668,141 \\
\hline Total assets of foreign banks (USD mn) & 129,481 & 18,671 & 91,247 & 161,199 \\
\hline Number of banks & 55 & 3 & 48 & 61 \\
\hline Number of foreign banks & 30 & 2 & 25 & 34 \\
\hline Total bank assets (USD mn) & 10,448 & 26,366 & 2 & 150,527 \\
\hline Loans to the domestic non-financial private sector (USD mn) & 4,693 & 12,187 & 0 & 75,952 \\
\hline Log changes in loans to the domestic non-financial sector & 0.7 & 15.7 & -99.3 & 95.7 \\
\hline \multicolumn{5}{|c|}{ Transmission Channel Statistics without country dimension (ratios in \%) } \\
\hline Liquid Assets / Total Assets & 22.0 & 25.8 & 0.0 & 100.0 \\
\hline Leverage & 8.4 & 10.2 & 0.0 & 94.7 \\
\hline C\&I Loans / Total Assets & 29.8 & 26.4 & 0.0 & 100.0 \\
\hline Securities / Total Assets & 10.1 & 14.9 & 0.0 & 90.1 \\
\hline \multicolumn{5}{|l|}{ Other Balance Sheet Controls (ratios in \%) } \\
\hline Log total assets & 7.0 & 1.9 & 0.4 & 11.6 \\
\hline Net IG funding ratio & 25.5 & 39.3 & -76.7 & 110.8 \\
\hline Core deposits ratio & 15.4 & 18.9 & 0.0 & 74.7 \\
\hline
\end{tabular}

Table 2b (Portugal): Statistics on channels and frictions

Ratios in \%. Period: 2006Q1-2015Q4.

\begin{tabular}{|c|c|c|c|c|}
\hline \multirow{2}{*}{ Variable (ratios in \%) } & \multicolumn{2}{|c|}{ US } & \multicolumn{2}{|c|}{ GB } \\
\hline & mean & sd & mean & sd \\
\hline Cross-border Liabilities from ctry/ Total Assets & 0.2 & 0.4 & 2.3 & 7.3 \\
\hline Net Cross-border Liabilities from ctry / Total Assets & -0.3 & 1.0 & 1.1 & 7.2 \\
\hline Cross-Border Assets in ctry / Total Assets & 0.4 & 1.1 & 1.2 & 3.5 \\
\hline Cross-Border Assets to Banks in ctry / Total Assets & 0.2 & 0.7 & 1.0 & 3.3 \\
\hline
\end{tabular}


Table 3: Funding frictions in the cross-border transmission of monetary policy - shadow rates

The dependent variable is log changes in loans to the domestic non-financial private sector. For Ireland, the data are quarterly from $2000 \mathrm{Q} 1$ to $2015 \mathrm{Q} 4$ for a panel of retail resident banks with foreign exposures (including subsidiaries, excluding branches). For Portugal, the data are quarterly from 2006Q1 to 2015Q4 for a panel of all resident banks with foreign exposures (including subsidiaries and branches). All specifications include fixed effects as specified in the lower part of the table. Standard errors are clustered by bank. Below the sum of the coefficients we report the p-values of the F-test. ***, **, and * indicate significance at the $1 \%, 5 \%$, and $10 \%$ level, respectively.

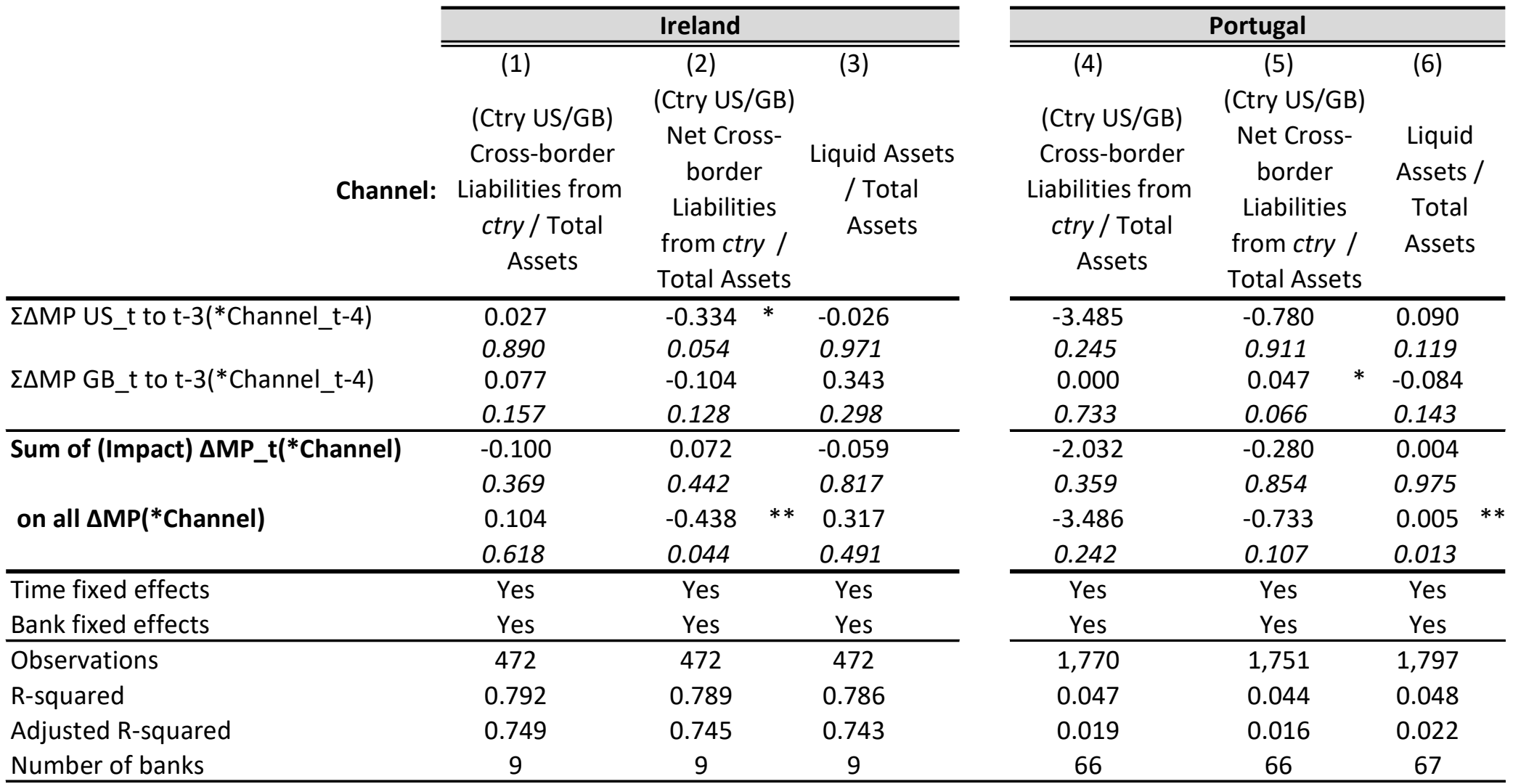

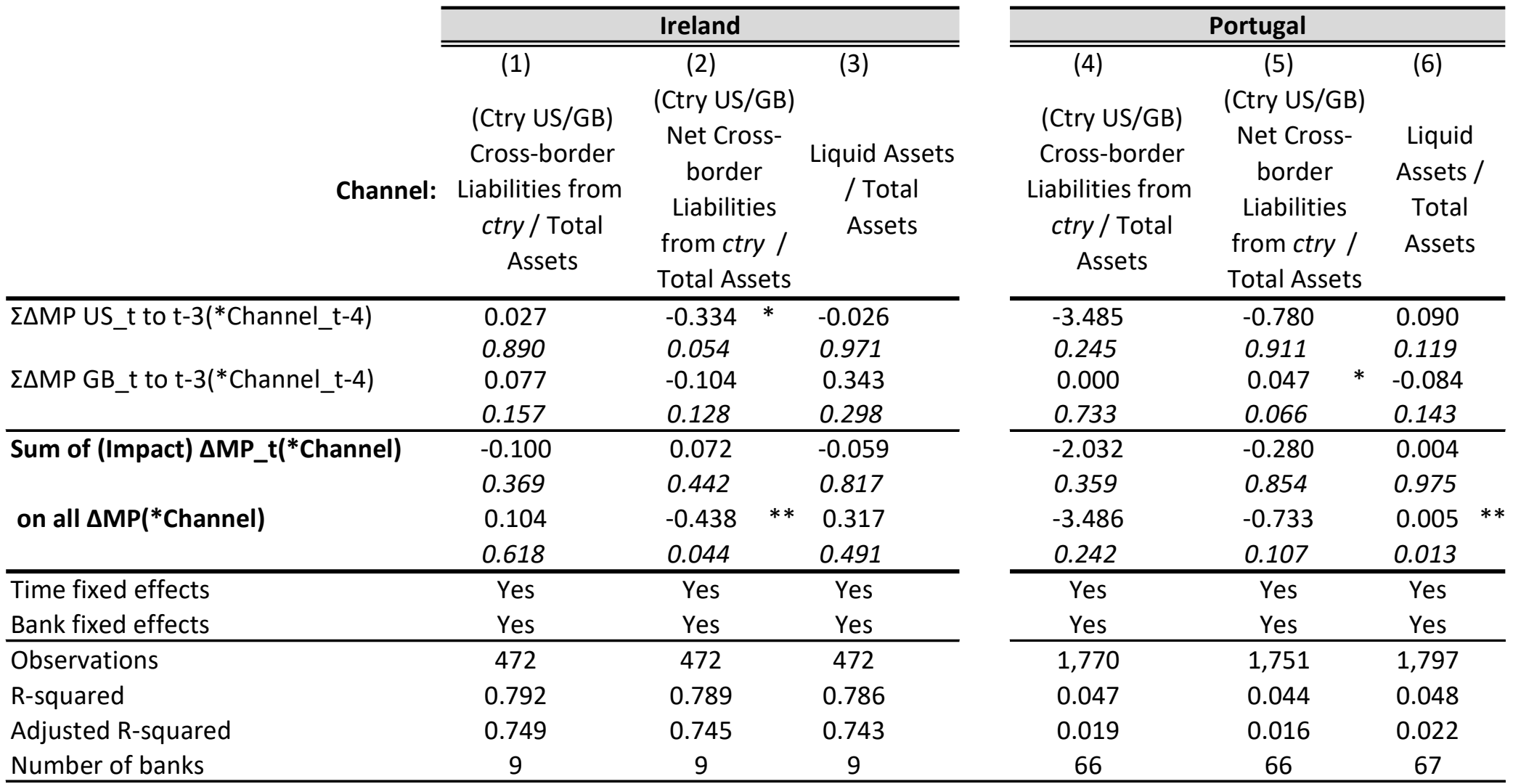


Table 4: Funding frictions in the cross-border transmission of monetary policy - Taylor residuals

The dependent variable is log changes in loans to the domestic non-financial private sector. For Ireland, the data are quarterly from $2000 \mathrm{Q} 1$ to $2015 \mathrm{Q} 4$ for a panel of retail resident banks with foreign exposures (including subsidiaries, excluding branches). For Portugal, the data are quarterly from $2006 \mathrm{Q} 1$ to $2015 \mathrm{Q} 4$ for a panel of all resident banks with foreign exposures (including subsidiaries and branches). All specifications include fixed effects as specified in the lower part of the table. Standard errors are clustered by bank. Below the sum of the coefficients we report the $\mathrm{p}$-values of the F-test. ${ }^{* *},{ }^{* *}$, and * indicate significance at the $1 \%, 5 \%$, and $10 \%$ level, respectively.

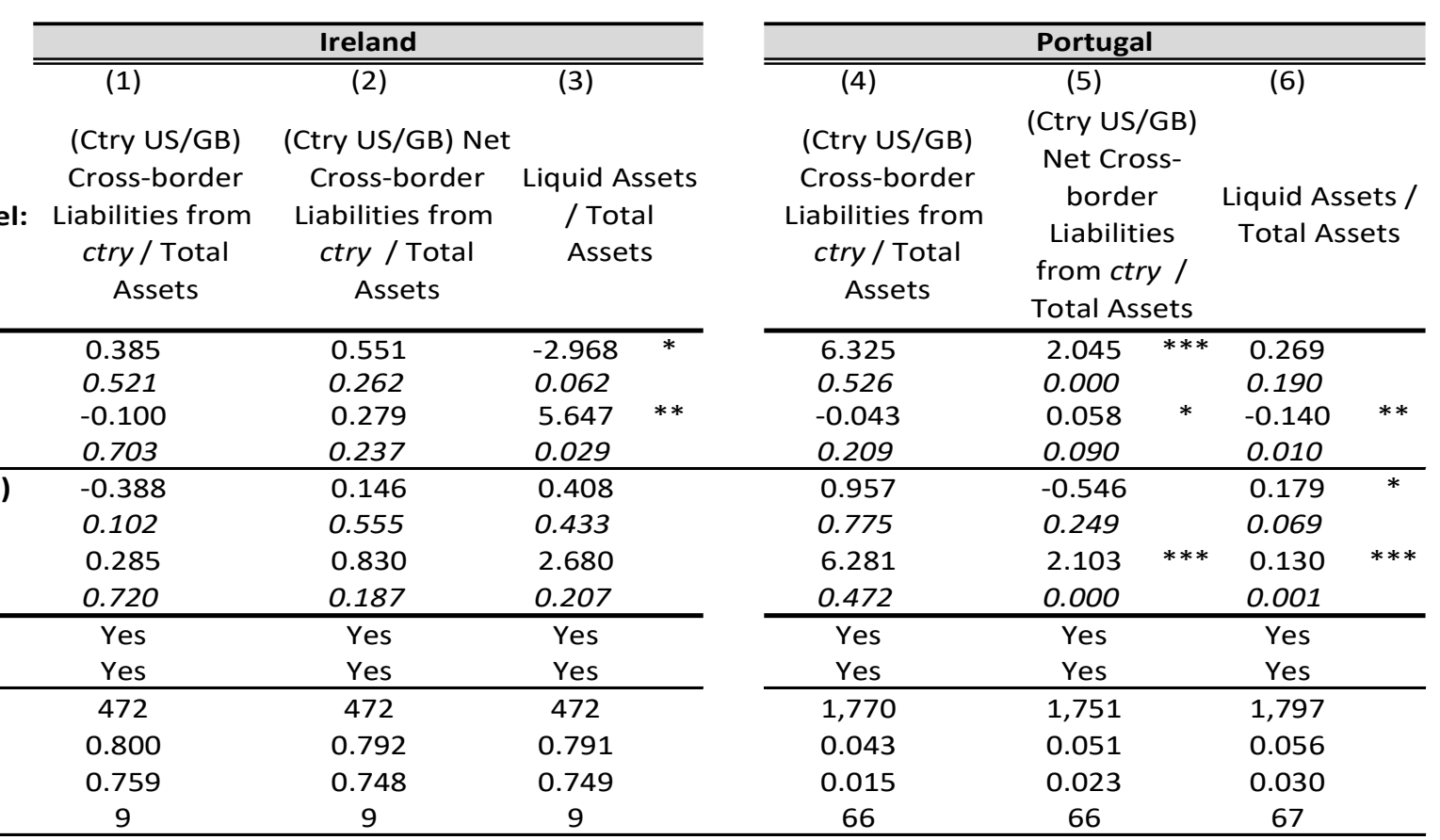


Table 5: Portfolio frictions in the cross-border transmission of monetary policy - shadow rates

The dependent variable is log changes in loans to the domestic non-financial private sector. For Ireland, the data are quarterly from $2000 \mathrm{Q} 1$ to $2015 \mathrm{Q} 4$ for a panel of retail resident banks with foreign exposures (including subsidiaries, excluding branches). For Portugal, the data are quarterly from 2006Q1 to 2015Q4 for a panel of all resident banks with foreign exposures (including subsidiaries and branches). All specifications include fixed effects as specified in the lower part of the table. Standard errors are clustered by bank. Below the sum of the coefficients we report the p-values of the F-test. $* * *, * *$, and $*$ indicate significance at the $1 \%, 5 \%$, and $10 \%$ level, respectively.

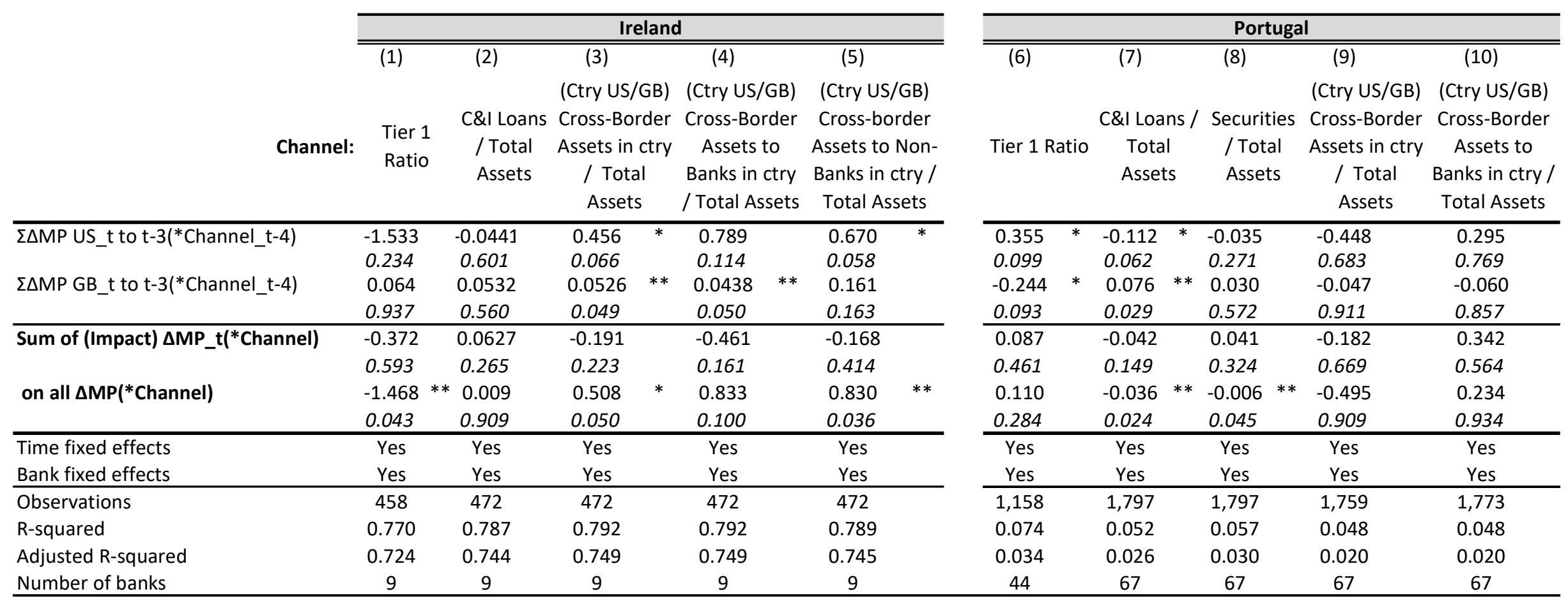




\section{Table 6: Portfolio frictions in the cross-border transmission of monetary policy- Taylor residuals}

The dependent variable is log changes in loans to the domestic non-financial private sector. For Ireland, the data are quarterly from $2000 \mathrm{Q} 1$ to $2015 \mathrm{Q} 4$ for a panel of retail resident banks with foreign exposures (including subsidiaries, excluding branches). For Portugal, the data are quarterly from 2006Q1 to 2015Q4 for a panel of all resident banks with foreign exposures (including subsidiaries and branches). All specifications include fixed effects as specified in the lower part of the table. Standard errors are clustered by bank. Below the sum of the coefficients we report the p-values of the F-test. ***, **, and * indicate significance at the $1 \%, 5 \%$, and $10 \%$ level, respectively.

\begin{tabular}{|c|c|c|c|c|c|}
\hline \multirow{7}{*}{ Channel: } & \multicolumn{5}{|c|}{ Ireland } \\
\hline & (1) & (2) & (3) & (4) & (5) \\
\hline & & & (Ctry US/GB) & (Ctry US/GB) & (Ctry US/GB) \\
\hline & & C\&I Loans & Cross-Border & Cross-Border & Cross-border \\
\hline & Ratio & / Total & Assets in ctry & Assets to & Assets to Non- \\
\hline & & & / Total & Banks in ctry & Banks in ctry / \\
\hline & & & & & \\
\hline \multirow[t]{2}{*}{$\Sigma \Delta \mathrm{MP}$ US_t to $\mathrm{t}-3\left({ }^{*}\right.$ Channel_t $\left.\mathrm{t}-4\right)$} & 5.564 & 0.127 & -0.623 & -1.191 & -0.781 \\
\hline & 0.418 & 0.710 & 0.367 & 0.407 & 0.474 \\
\hline \multirow{2}{*}{$\Sigma \Delta \mathrm{MP}$ GB_t to $\mathrm{t}-3\left({ }^{*}\right.$ Channel_t -4$)$} & 4.082 & 0.0695 & -0.101 & -0.131 & 0.319 \\
\hline & 0.594 & 0.744 & 0.611 & 0.550 & 0.523 \\
\hline \multirow[t]{2}{*}{ Sum of (Impact) $\Delta M P_{-} t\left({ }^{*}\right.$ Channel) } & 2.548 & 0.0893 & -0.388 & $-0.842 \quad * *$ & -0.435 \\
\hline & 0.166 & 0.418 & 0.140 & 0.049 & 0.202 \\
\hline \multirow[t]{2}{*}{ on all $\Delta \mathrm{MP}\left({ }^{*}\right.$ Channel) } & 9.647 & 0.197 & -0.724 & -1.322 & -0.462 \\
\hline & 0.221 & 0.614 & 0.356 & 0.390 & 0.560 \\
\hline Time fixed effects & Yes & Yes & Yes & Yes & Yes \\
\hline Bank fixed effects & Yes & Yes & Yes & Yes & Yes \\
\hline Observations & 458 & 472 & 472 & 472 & 472 \\
\hline R-squared & 0.773 & 0.789 & 0.792 & 0.791 & 0.787 \\
\hline Adjusted R-squared & 0.727 & 0.746 & 0.749 & 0.748 & 0.743 \\
\hline Number of banks & 9 & 9 & 9 & 9 & 9 \\
\hline
\end{tabular}

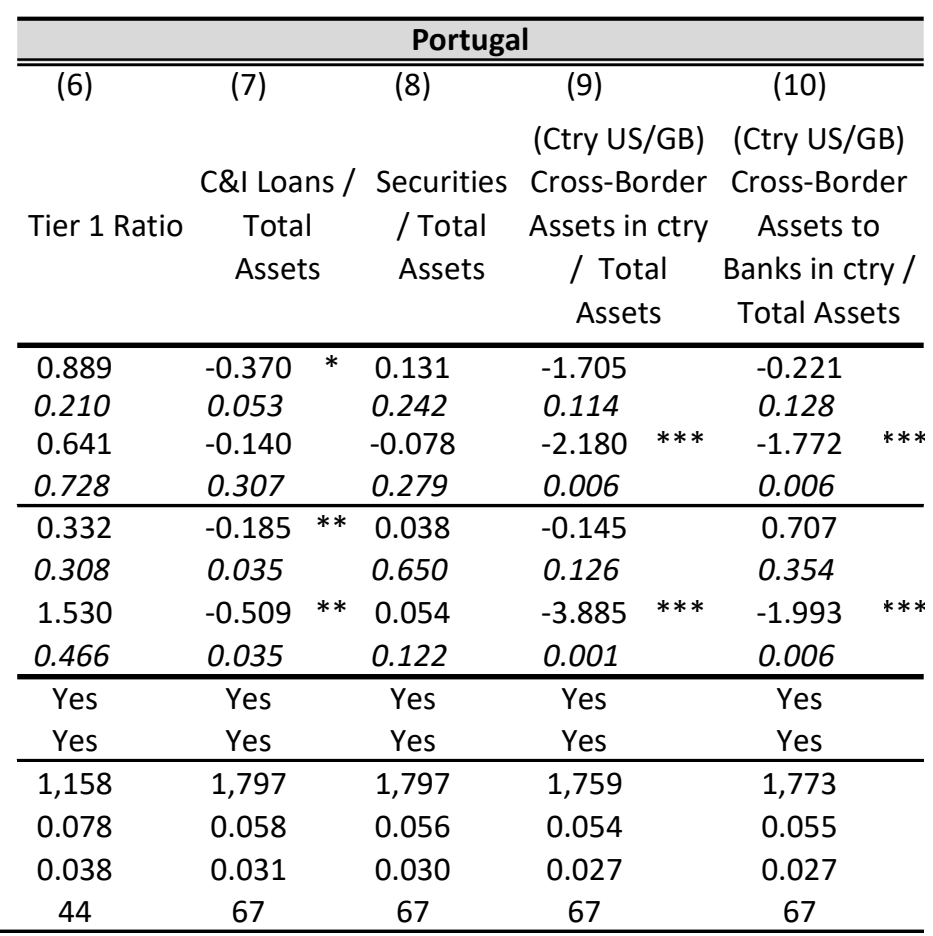




\section{Table 7: Funding frictions before and after the start of the euro area sovereign debt crisis - shadow rates}

The dependent variable is log changes in loans to the domestic non-financial private sector. For Ireland, the data are quarterly from $2000 \mathrm{Q} 1$ to $2015 \mathrm{Q} 4$ for a panel of retail resident banks with foreign exposures (including subsidiaries, excluding branches). For Portugal, the data are quarterly from 2006Q1 to 2015Q4 for a panel of all resident banks with foreign exposures (including subsidiaries and branches). All specifications include fixed effects as specified in the lower part of the table. Standard errors are clustered by bank. Below the sum of the coefficients we report the p-values of the F-test. ***, **, and * indicate significance at the $1 \%, 5 \%$, and $10 \%$ level, respectively.

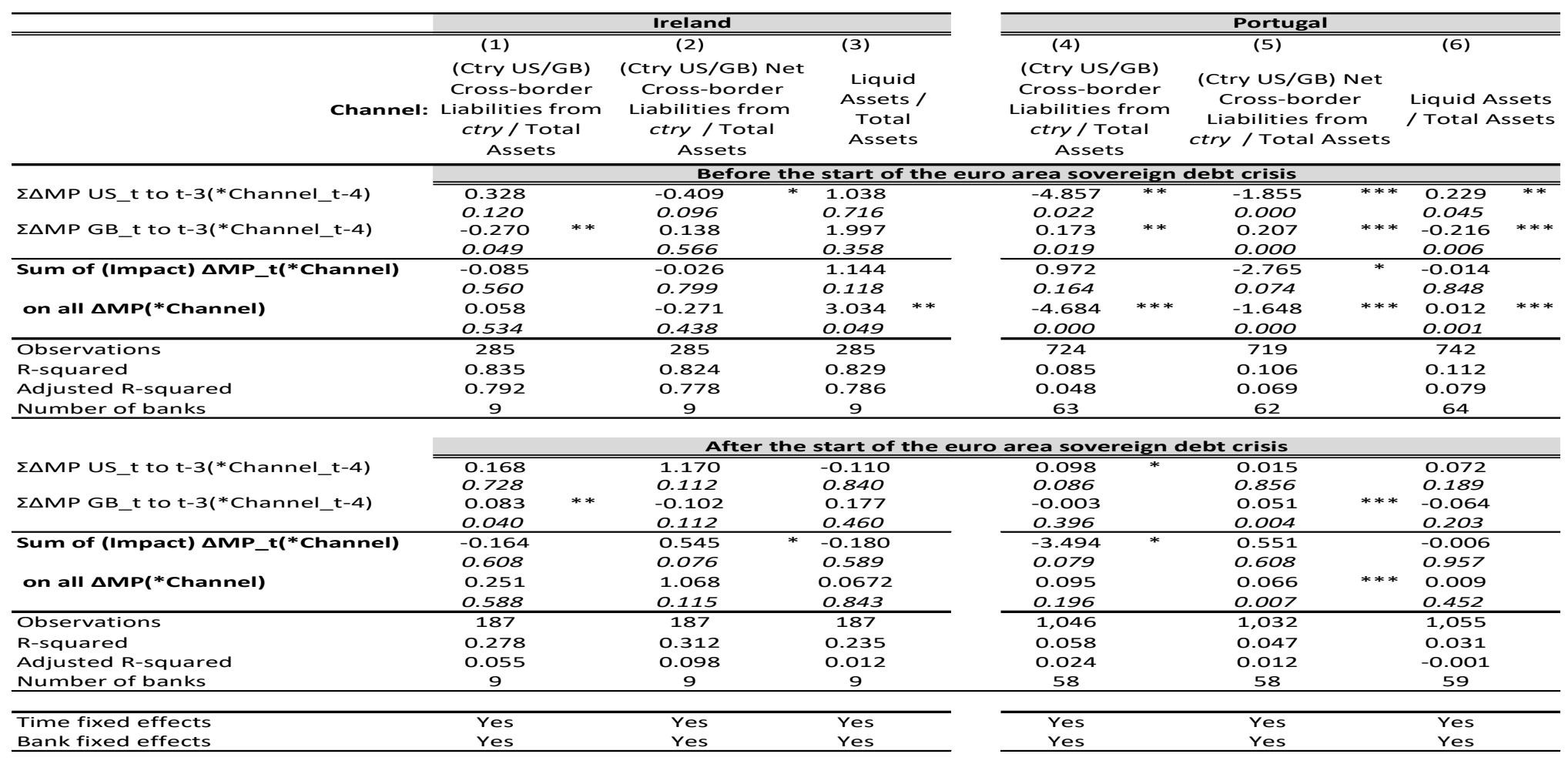




\section{Table 8: Portfolio frictions before and after the start of the euro area sovereign debt crisis - shadow rates}

The dependent variable is log changes in loans to the domestic non-financial private sector. For Ireland, the data are quarterly from $2000 \mathrm{Q} 1$ to $2015 \mathrm{Q} 4$ for a panel of retail resident banks with foreign exposures (including subsidiaries, excluding branches). For Portugal, the data are quarterly from 2006Q1 to 2015Q4 for a panel of all resident banks with foreign exposures (including subsidiaries and branches). All specifications include fixed effects as specified in the lower part of the table. Standard errors are clustered by bank. Below the sum of the coefficients we report the p-values of the F-test. ***, **, and * indicate significance at the $1 \%, 5 \%$, and $10 \%$ level, respectively.

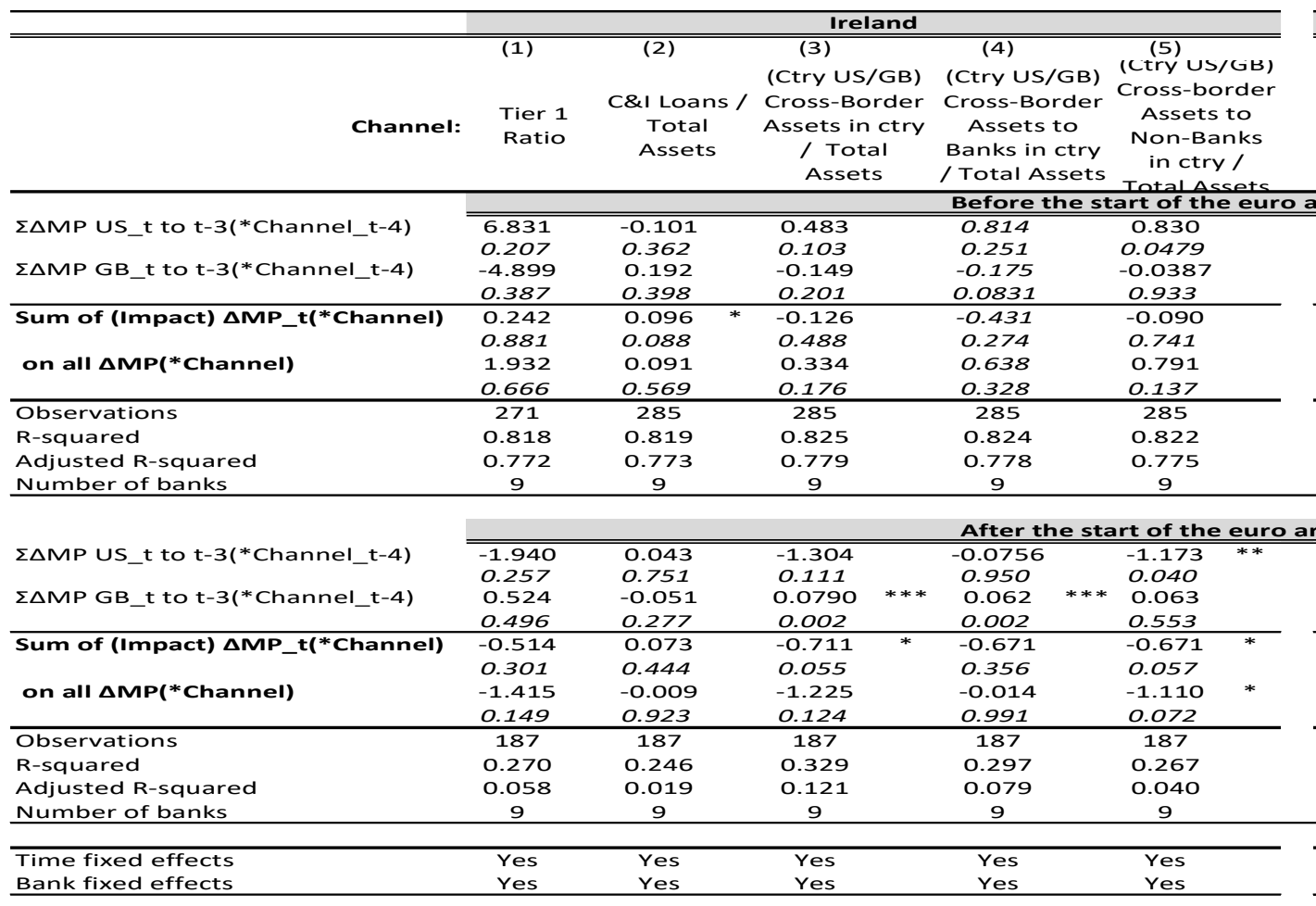

\begin{tabular}{|c|c|c|c|c|}
\hline \multicolumn{5}{|c|}{ Portugal } \\
\hline (6) & (7) & (8) & (9) & (10) \\
\hline $\begin{array}{l}\text { Tier } 1 \\
\text { Ratio }\end{array}$ & $\begin{array}{l}\text { C\&I Loans } \\
\text { / Total } \\
\text { Assets }\end{array}$ & $\begin{array}{l}\text { Securities } \\
\text { / Total } \\
\text { Assets }\end{array}$ & $\begin{array}{c}\text { (Ctry US/GB) } \\
\text { Cross-Border } \\
\text { Assets in ctry } \\
\text { / Total } \\
\text { Assets }\end{array}$ & $\begin{array}{c}\text { (Ctry US/GB) } \\
\text { Cross-Border } \\
\text { Assets to } \\
\text { Banks in ctry } \\
\text { / Total Assets }\end{array}$ \\
\hline \multicolumn{5}{|c|}{ rea sovereign debt crisis } \\
\hline 0.901 & $-0.144^{* *}$ & $-0.160^{*}$ & 2.065 & 4.056 \\
\hline $\begin{array}{l}0.126 \\
-0.859\end{array}$ & $\begin{array}{l}0.040 \\
0.069\end{array}$ & 0.001 & 0.126 & 0.000 \\
\hline 0.065 & 0.281 & 0.425 & 0.623 & 0.633 \\
\hline-0.061 & $\begin{array}{lll}* & -0.107 & * *\end{array}$ & $0.340 * * *$ & 2.630 & 4.970 \\
\hline 0.097 & 0.038 & 0.004 & 0.154 & 0.003 \\
\hline 0.042 & $-0.075 * *$ & $0.246 * * *$ & 1.803 & 3.745 \\
\hline 0.201 & 0.025 & 0.005 & 0.253 & 0.000 \\
\hline 469 & 742 & 742 & 726 & 735 \\
\hline 0.132 & 0.095 & 0.079 & 0.088 & 0.093 \\
\hline 0.081 & 0.060 & 0.045 & 0.051 & 0.057 \\
\hline 42 & 64 & 64 & 63 & 64 \\
\hline \multicolumn{5}{|c|}{ rea sovereign debt crisis } \\
\hline 0.341 & -0.072 & -0.043 & -0.489 & 0.486 \\
\hline 0.152 & 0.920 & 0.875 & 0.839 & 0.458 \\
\hline $\begin{array}{l}-0.213 \\
0.519\end{array}$ & $\begin{array}{l}0.030 \\
0.749\end{array}$ & $\begin{array}{l}0.056 \\
0.516\end{array}$ & $\begin{array}{l}-0.022 \\
0.720\end{array}$ & $\begin{array}{l}-0.056 \\
0.677\end{array}$ \\
\hline 0.043 & -0.016 & 0.017 & -0.787 & -0.570 \\
\hline 0.379 & 0.533 & 0.344 & 0.382 & 0.537 \\
\hline 0.128 & -0.042 & 0.014 & -0.511 & 0.431 \\
\hline 0.170 & 0.791 & 0.416 & 0.672 & 0.357 \\
\hline 689 & 1,055 & 1,055 & 1,033 & 1,038 \\
\hline 0.048 & 0.04 & 0.037 & 0.044 & 0.042 \\
\hline-0.001 & 0.011 & 0.004 & 0.009 & 0.007 \\
\hline 36 & 59 & 59 & 59 & \\
\hline & & & & \\
\hline & & & Yes & $Y \in$ \\
\hline
\end{tabular}

Tank fixedeffects

Yes

Yes
Yes

Yes

Yes
Yes

Yes
Yes 


\section{Appendix 1 - Variables definition}

\begin{tabular}{|c|c|c|c|c|}
\hline \multirow{2}{*}{ Variable Name } & \multirow{2}{*}{ Description } & \multicolumn{2}{|c|}{ Data Source } & \multirow{2}{*}{ Comments } \\
\hline & & IE & PT & \\
\hline Change in $\mathrm{Y}$ & $\left.\log (\text { Total Loans })_{t}\right)-\log \left(\right.$ Total Loans $\left._{\left.\mathrm{t}_{-1}\right)}\right)$ & $\begin{array}{l}\text { Monthly balance sheet statistics } \\
\text { (Central Bank of Ireland) }\end{array}$ & $\begin{array}{l}\text { Supervisory data } \\
\text { (Banco de Portugal) }\end{array}$ & $\begin{array}{l}\text { For the irish data the growth rate of credit is used which pure } \\
\text { credit growth having excluded securitisations, write offs etc. }\end{array}$ \\
\hline Log Assets & $\begin{array}{c}\log \text { (Total assets*(GDP deflator 2012/GDP } \\
\text { deflator)) }\end{array}$ & $\begin{array}{l}\text { Monthly balance sheet statistics } \\
\text { (Central Bank of Ireland) }\end{array}$ & $\begin{array}{c}\text { Supervisory data (Banco de } \\
\text { Portugal) and National accounts } \\
\text { (Statistics Portugal) }\end{array}$ & \\
\hline Tier 1 ratio & $\begin{array}{l}\text { (Tier } 1 \text { risk-based capital / Risk-weighted } \\
\text { assets) } * 100\end{array}$ & SNL & $\begin{array}{l}\text { Supervisory data } \\
\text { (Banco de Portugal) }\end{array}$ & \\
\hline Leverage & (Capital/Total Assets) (in \%) & & $\begin{array}{l}\text { Supervisory data } \\
\text { (Banco de Portugal) }\end{array}$ & \\
\hline Liquid Asset Ratio & $\begin{array}{c}(\text { Cash }+ \text { liquid securities/Total assets)) (in } \\
\%)\end{array}$ & $\begin{array}{l}\text { Monthly balance sheet statistics } \\
\text { (Central Bank of Ireland) }\end{array}$ & $\begin{array}{l}\text { Supervisory data } \\
\text { (Banco de Portugal) }\end{array}$ & $\begin{array}{l}\text { For Portugal we consider an adapted definition, due to data } \\
\text { availability constraints: (Cash and claims on central banks and } \\
\text { credit institutions/Total assets)) (in \%). This definition is } \\
\text { different from that used in other countries due to differences in } \\
\text { the supervisory reporting templates. Their correlation should } \\
\text { nonetheless be high. }\end{array}$ \\
\hline Net intragroup funding & $\begin{array}{l}\text { (Liabilities from own offices - Claims on } \\
\text { own offices)/Assets) * } 100\end{array}$ & $\begin{array}{l}\text { Monthly balance sheet statistics } \\
\text { (Central Bank of Ireland) }\end{array}$ & $\begin{array}{c}\text { Monthly balance sheet statistics } \\
\text { and supervisory data (Banco de } \\
\text { Portugal) }\end{array}$ & $\begin{array}{l}\text { For Portugal we consider an adapted definition, due to data } \\
\text { availability constraints: (Deposits of banks of the same banking } \\
\text { group located abroad - credit, debt securities shares and other } \\
\text { equity to banks of the same banking group located abroad } \\
\text { )/Total liabilities (in \%) }\end{array}$ \\
\hline Core Deposits Ratio & \begin{tabular}{|c|}
$\begin{array}{c}\text { Time deposits from residents }+ \text { deposits } \\
\text { redeemable at notice from residents }+ \\
\text { savings deposits from residents )/Total assets } \\
\text { (in \%) }\end{array}$ \\
\end{tabular} & $\begin{array}{l}\text { Monthly balance sheet statistics } \\
\text { (Central Bank of Ireland) }\end{array}$ & $\begin{array}{l}\text { Supervisory data } \\
\text { (Banco de Portugal) }\end{array}$ & \\
\hline C\&I Loans / Total Assets & C\&I Loans / Total Assets (in \%) & $\begin{array}{l}\text { Monthly balance sheet statistics } \\
\text { (Central Bank of Ireland) }\end{array}$ & $\begin{array}{l}\text { Supervisory data } \\
\text { (Banco de Portugal) }\end{array}$ & $\begin{array}{l}\text { For Portugal we consider an adapted definition, due to data } \\
\text { availability constraints: Domestic loans to firms and general } \\
\text { government / Total Assets (\%) }\end{array}$ \\
\hline Securities / Total Assets & Securities / Total Assets (in \%) & & $\begin{array}{l}\text { Supervisory data } \\
\text { (Banco de Portugal) }\end{array}$ & \\
\hline $\begin{array}{l}\text { Cross-border Liabilities from } \\
\text { ctry/ Total Assets }\end{array}$ & $\begin{array}{l}\text { (Cross-border liabilities from } \\
\text { ctry/Assets)* } 100\end{array}$ & $\begin{array}{r}\text { Bank level data underlying the re } \\
\text { Statistics }\end{array}$ & $\begin{array}{l}\text { ort to the International Banking } \\
\text { the BIS }\end{array}$ & \\
\hline $\begin{array}{l}\text { Net Cross-border Liabilities from } \\
\text { ctry / Total Assets }\end{array}$ & $\begin{array}{l}\text { ((Cross-border liabilities from ctry-Cross- } \\
\text { border assets from ctry }) / \text { Assets)* } 100\end{array}$ & $\begin{array}{r}\text { Bank level data underlying the re } \\
\text { Statistics }\end{array}$ & $\begin{array}{l}\text { ort to the International Banking } \\
\text { the BIS }\end{array}$ & \\
\hline $\begin{array}{l}\text { Cross-Border Assets in ctry / } \\
\text { Total Assets }\end{array}$ & (Cross-border claims on ctry/Assets)*100 & $\begin{array}{r}\text { Bank level data underlying the re } \\
\text { Statistics }\end{array}$ & $\begin{array}{l}\text { ort to the International Banking } \\
\text { the BIS }\end{array}$ & \\
\hline $\begin{array}{c}\text { Cross-Border Assets to Banks in } \\
\text { ctry / Total Assets }\end{array}$ & $\begin{array}{l}\text { (Cross-border claims to banks on } \\
\text { ctry/Assets)*100 }\end{array}$ & $\begin{array}{r}\text { Bank level data underlying the re } \\
\text { Statistics }\end{array}$ & $\begin{array}{l}\text { ort to the International Banking } \\
\text { the BIS }\end{array}$ & \\
\hline $\begin{array}{l}\text { Cross-border Assets to Non- } \\
\text { Banks in ctry / Total Assets }\end{array}$ & $\begin{array}{l}\text { (Cross-border claims to non-banks on } \\
\text { ctry/Assets)*100 }\end{array}$ & $\begin{array}{r}\text { Bank level data underlying the re } \\
\text { Statistics }\end{array}$ & $\begin{array}{l}\text { ort to the International Banking } \\
\text { the BIS }\end{array}$ & \\
\hline
\end{tabular}


www.bportugal.pt 